4Qa1大根芥子油の水及びアルコール共存下における反忘生成物の棈诰

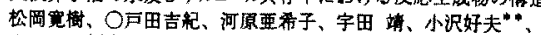

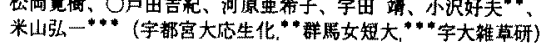

【目的】演者らは大根の主辛味成分、4・メチルチオ・3・フテニルイソチオシ

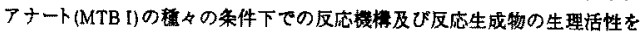

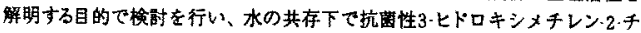

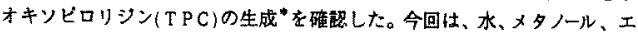

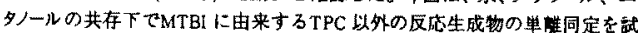

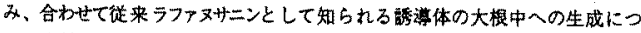
いても湌村した。

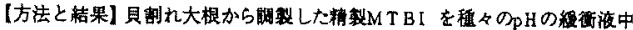

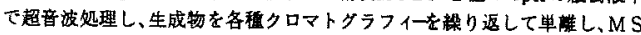

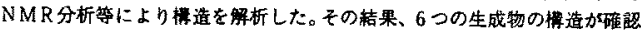
された。これらは、主生成物のTPCの他、(Z)及び(E)·-methylthio-methylene 2-thioxopyrrolidines, methyl $4 \cdot(Z)$ methylthio-3-butenyldithiocarbanate, methyl $4-(E)$-methylthio 3 - butenyldithiocarbamate. metbyl 4 methylbutyldithiocarba-

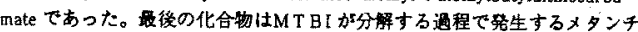
オールのジメチルシスルフィドへの酸化に伴い生成することが唭められた。 次に、ラファヌサニンの大根中への生成を磪諝するために、大根及び貝割れ大

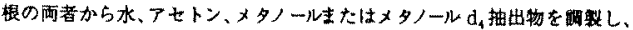
GCMS分析を行った結果、ラフフヌサニンは水及びフセトン抽出物からは格

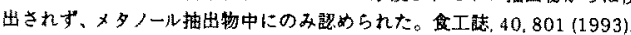

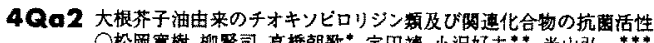

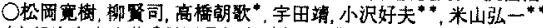

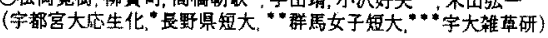

【目的】演者らは大根の主辛味战分、メチルチオ・3ブテニルインチオシア ナート(MTBI)の植々の策件下で反応機潇及び反応生成物の生理活性を解 明する目的で梌尉を行い、MTBI は水の共存下でチオキンビロリシン及びシ チオカーバメートの生成を確証した。ここでは、これらの化合物及び関連合

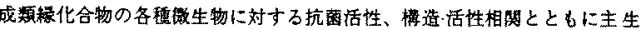

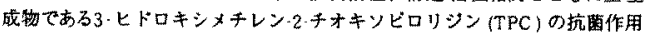

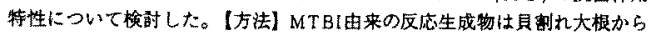

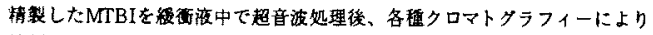

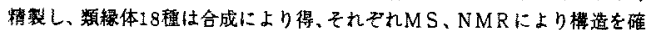

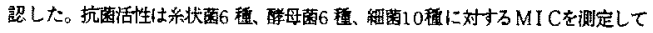
比した TPCについては、主にStaphylococcusepidermidis 用いて、

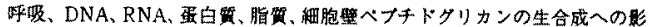

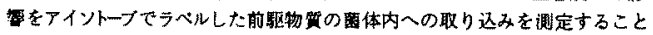
により检尉した。【粘果】MTBIから水共存下で得られる6 程の化合物のう

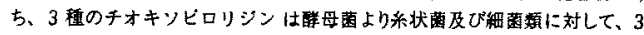

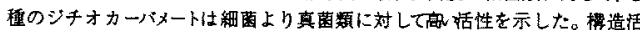

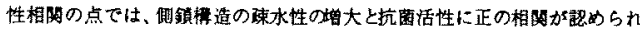

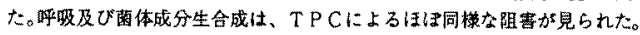

4Q03 食品夕ンパク貿の梅造に及ばす大豆サボニンの影電

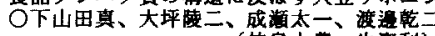

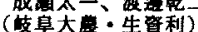

【目的】昨年度の大会において演者らはsoyasaponin Iが大豆卜リ

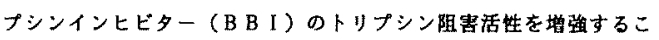

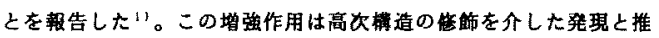
利されたので、B B I を始め数種のタンパク算を用い、大豆サポ二

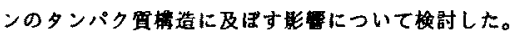

【方法】供歌タンパク質としてB B 1の他に、ウシ血清アルフミン (B S A )、畉白オボアルプン (OV)、ウシ $B$ ーラクトグフ リン $(\beta-L \mathrm{~g})$ 老用いた。高猜造解析にはC D、N M Rの他、

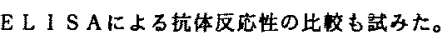

【結果】B S A の抗体反応性と C D スペクトルは、大豆サポニンの 加によって期整されなかった。一方、B BIは CDスベクトルが

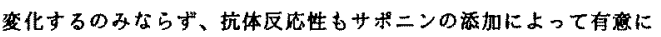
低下し、エピトープ部分が售飾されているものと考元られた。さら にOV、 $\beta-\mathrm{Lg}$ についてもCD、NMR等を用いて高娷造に及 ばす大豆サポニンの夦について桹討した。

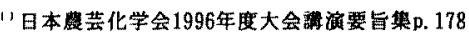

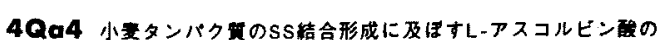
an

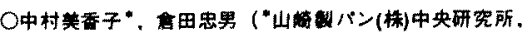
お莱の水女子大・生活琚境研究せンター)

1.目的 Lーアスコルビン酷(AsA)は食品タンバク貫におけるSH-SS 交 换反広を介して、その物性形成に奇与することが示唚されているが反

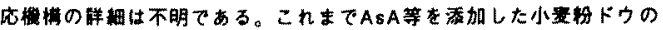

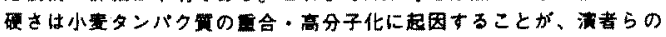

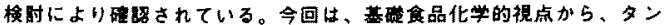

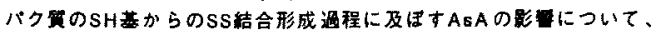
毁算化学的手法に上る解析を琙みた。

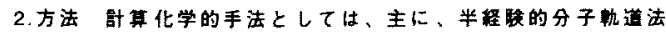
MOPAC (J.J.P. Stewart, Ver. 6.0)を用い、主としてPM3ハミル トニアンにより䂥策を行った。

3.䠜果 SH悬を持つ化合物のモデル系として、システィン・クルタ

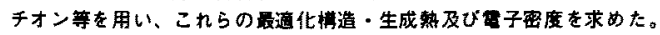
システイン及びタルタチオンの解辟型ではS原子にHOMOが局在して いることが㰮められた。さらに、これらと酸化型AsAとの反约につい

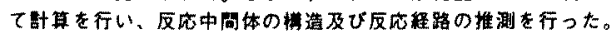

\section{$4 Q a 5$}

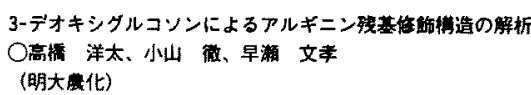

1. 目的 Ma II ard 反度中同生成物の 3-デオキシグルコンン (30G)による タンバク買のアルギニン残基住飾生成物の 1 つで主要中同体である 12

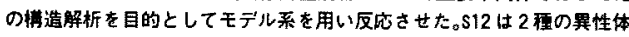

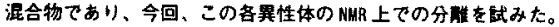

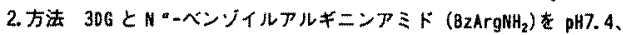

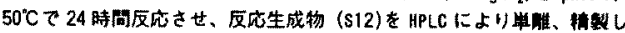

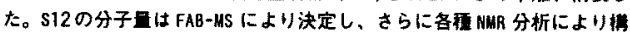
造解析を行った。

3.结果 S12 はFAB-MS、高分解FAB-HS 分析により、分子且 421、分子 式 $\mathrm{C}_{19} \mathrm{H}_{27} \mathrm{O}_{6} \mathrm{~N}_{5}$ と決定され、また各政

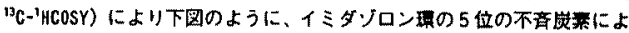

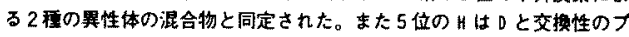
ロトンであった。<smiles>[R]NC1=NC(=O)[C@H]([R2])N1</smiles>

$\mathrm{R}_{7}=\left(\mathrm{CH}_{2}\right)_{2} \mathrm{CH}\left(\mathrm{NHCOC} \mathrm{CH}_{5}\right) \mathrm{CONH}_{2}$ $\mathrm{R}_{2}=\mathrm{CH}_{2}(\mathrm{CHOH})_{2} \mathrm{CH}_{2} \mathrm{OH}$

4Q96 3ーデオキシグルコンンによるD N A 徏既生成物の解析

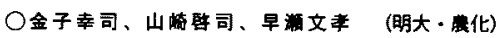

1)目的 前回、メイラード反统の中同生成物である3ーデオキシタルコ ソン（3DG）の变異原性及びDNAとの反沁についてモデル系を用い 解析した。”本研究では、3DGと最も反性の高かった2一 deoxyguanosine (dG) との反生成物の倳造解析を行った。 2)方法 $\mathrm{dG}(100 \mathrm{mM})$ と $3 \mathrm{D} \mathrm{G}(100 \mathrm{mM})$ を $\mathrm{pH7} .4 .50^{\circ} \mathrm{C} て ゙ 6$ 日同反记さ

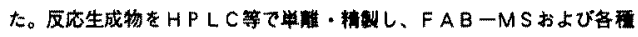
NMRにより梏舴析を行った。また、Call Thymus DNA (45unit) と

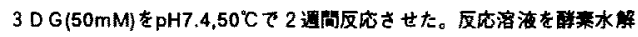
し、HPLCにより分析した。

3)結果 3DGとdGの反応系の主要生成物は2 植(G-A,G-B)であった。

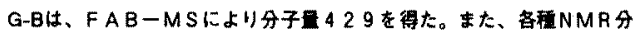
析により $N$-(1-oxo-2,4,5,6-hydroxyhexyl)-2'-deoxyguanosineと同定し た。G-AとG-Bは光学翼性体であった。DNAと3DGの反応において もG-A,G-Bが生成した。

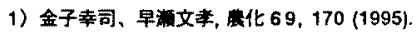


$4 \mathrm{Qa7}$ タンパク頨のグリケーションにより生成ナるジカルボニル佮物の 㮛比・定

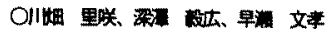
(明大贯(t)

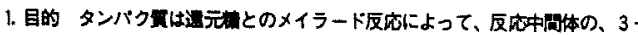

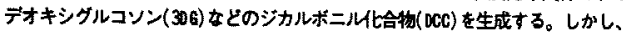

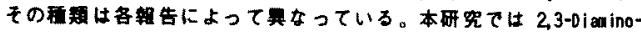

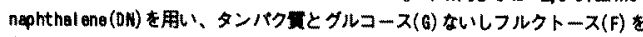

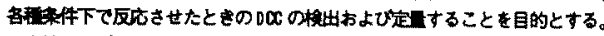
2 方法 リゾチーム $(L ; 10 \mathrm{mg} / \mathrm{ml})$ と各 $200 \mathrm{mMO} \mathrm{G,F} \mathrm{とG，F} \mathrm{のみを} \mathrm{pHT} .4,50^{\circ} \mathrm{C}$,

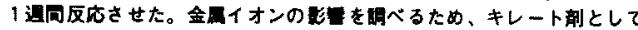

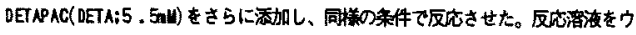

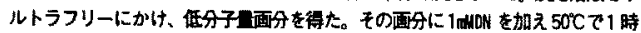
䛀店させ、UPC分析を们った。

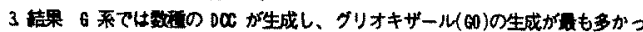

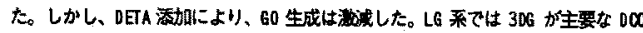

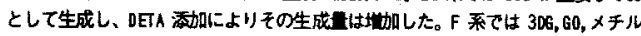

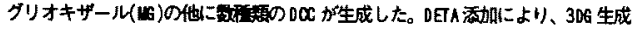

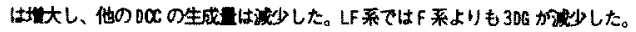

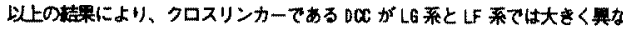

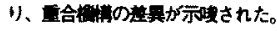

$49 a 8$ 蛋白䨘のメチルダリオキザール㑑锦 ○内田浩二、許 偉展、大澤俊彦 (名大哏応用生物)

【目的】 Methylglyoxal (MG) はアミノカルボニル反分や脂 䁈過酸化反応などの食品成分間反店において生成される变翼 原物曾であるほか、糖尿病患者の血中に括ける有意な增加が 報告されている。本研究ではMGによる蛋白實アルキル化反椨 を解析するととるに、抗MG付加蛋白質抗体の作成、及ひ抗体 の特異性の解析を行った。

【方法及び結果】蛋白筫(BSA) (10mg/mi) を MG (100mM) とリン酸瑷衙液( $\mathrm{pH} 7.2)$ 中、 $37^{\circ} \mathrm{C}$ 反底を行い、アミノ䣷分析 により標的アミノ酸及びMG付加アミノ酸の検出を行った。そ の結果、MGはこれまでの報告通りLys,Argに特異的に作用し た。また、Lys,Argの䛈導体とMGとの反応から Imidazolysine

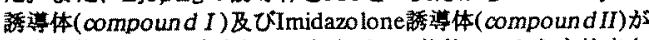
主生成物として同定され、これらはMG修飾BSAからも梌出さ れた。これらの付加体の特巽的㛟出系の構築を目的に抗体作 成を行った。兔投原にはMG修飾KLH及び、compoundIIKLH conjugateを用いた。それそれの抗体の特算性を調べたと ころ、抗MG-KLH抗体のみがMG修飾蛋白質を懿識し、さら にcompound IIがエビトーブを構成していることが判明した。

4Qa9 メイラード反応で生じた親水性過酸化分子によるヒト 血清アルプミンの架摛化とリホ蛋白の酸化修飾

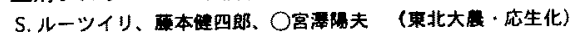

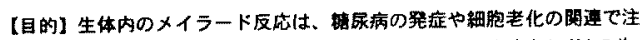

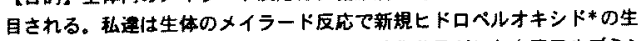
成を先に訆めたか、ここではこの新水性通酸化分子がヒト血消アルフミン

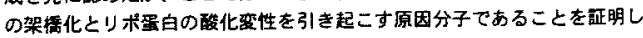
たのて堑告する。

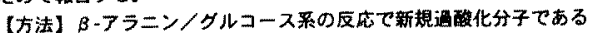
HMDP* (ヒトロキシヒドロベルオキシメチルジヒトロビラノン) を分取 し、これを反応に用い、生成物をSDS-PAGEおよびカロースゲル西氮涾 助に供して耛へた。

【結果】ヒト血清アルフミン (HSA) をHMDPと生理的条件で反応させる

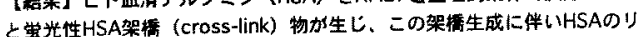

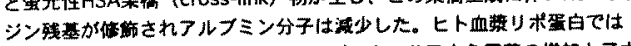

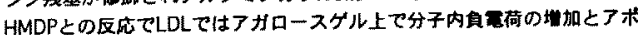

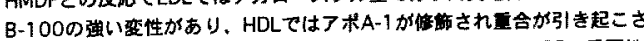
れた。本結果は、生体メイラード反乘による赥胞陮害でのHMPの重要性 を示した。

*S. Lertsiri et al. Biochim. Biophys. Acta, 1245, 278 (1995)
4Qa10榙尿病モテルラットにおけるパイオマーカーMRXについて O大矢友子、小林弘行"、秋莱光雄"，柿本紀博"

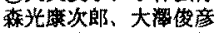

(名大震・地生科、“浅井ゲルマニウム研)

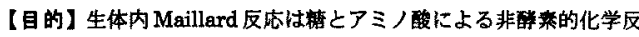
応であり、この反応の後期段階で生成する advanced glycation end products (AGEB) は情尿病合并症のバイオマーカーとして重要な役 割を果たしている。演者らは精展病患者の血没を加水分解することに

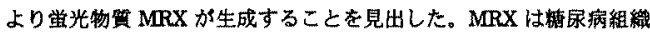
や尿中タンバク留の加水分解物において大量に桱出されることから 榶尿病合併症におけるマーカーとなり得る事が予想される。そこで、 MRXの化学的棰造解析を行い、生成機楼についても梌㣙した。

【方法及ひ秙果】湖尿病自然発症モデル OLET-Fラットの尿中タン バク筫を加水分解し、HPLCによる定量分析を行った結果、正常ラッ 卜に比へ有意に MRX 排泄量が增加していることが明らかとなった。

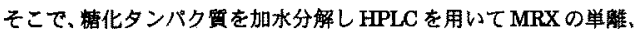
精製を行った。各種㙨器分析の結果、6 炭粕とシステインが樎合した 楎造と同定することができた。しかし、MRXの生成にはクルルコース とシステイン（あるい怯シスチン）とグコジ基が必要であり、タ ンパク買に結合している看䁫体の存在が示唆された。現在、化学的合

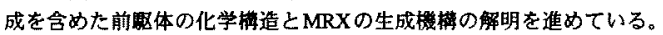

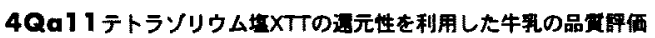

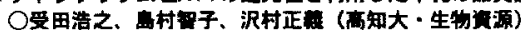

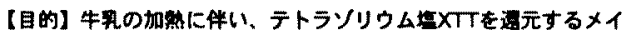

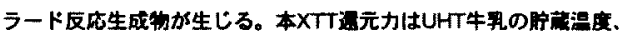

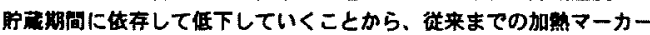

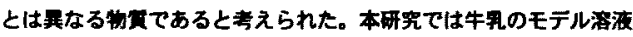

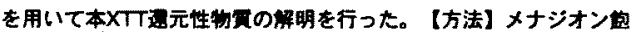

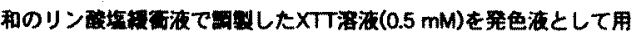
いた。クリコールアルデヒド(GA)とタリオキザール(GX)济度は MBTH法で测定した。牛れモテル溶浓としてカせイン(2.6\%)と瞵

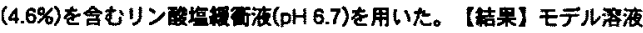

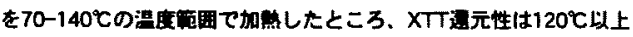
で急速に生成することが明らかとなった。一方クリシンと各的カル

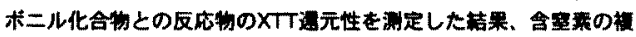

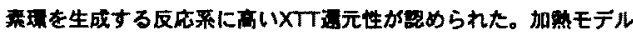

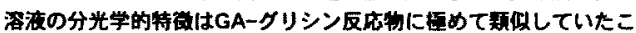

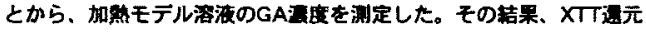

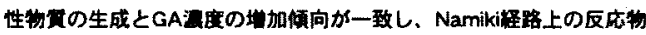

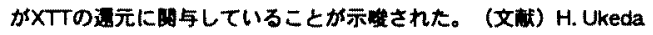
et al., Food Sci. Technol., Int., 1, 52 (1995); ibid. 2, 48 (1996).

4Qa 12 Luciferin-LuciferaseとSalmonella spp.を用いる

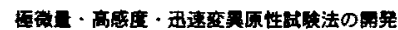

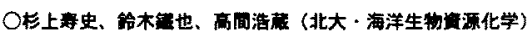

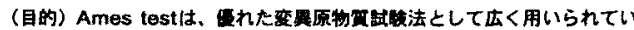

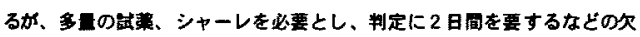
点もあり、县っ改良が䮏みられている。演者らは、Ames testの省エネか

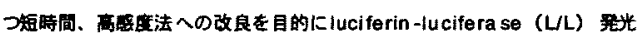

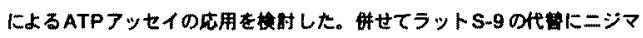

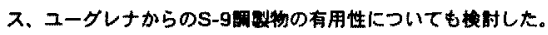

(万法と結果) 使用整株はSalmonella typhimurium TA98まよU

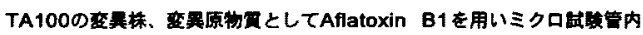

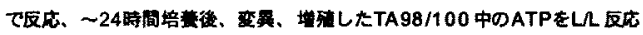

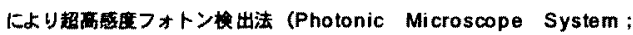
ARGUS-100）により定留的に测定した。本法により、徉来方法に比へ

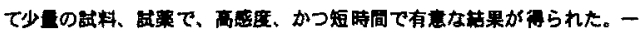

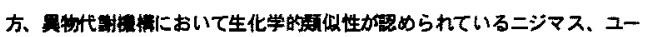

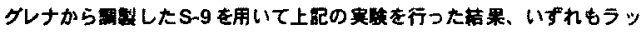
トS-9の代㫪物としての有用性汃示された。 


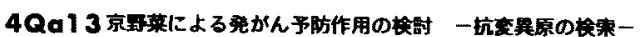

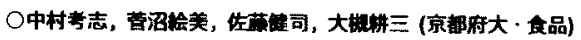

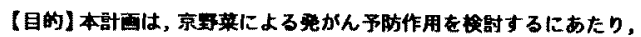

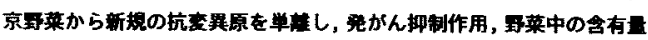

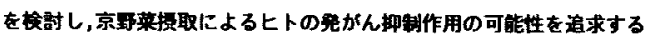
ことを目的としている，その第一段䐗として，各玨京輮莱の抽出物につ

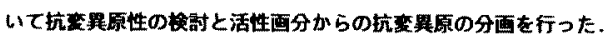

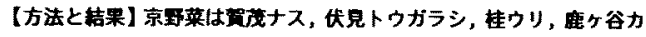

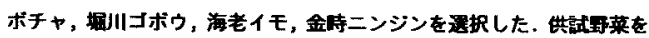
蒸留水中で破䃑，メタノールで抽出後，nーヘキサン，クロロホルム，百

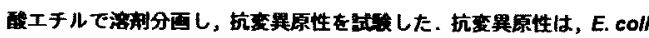

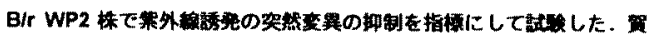
茂ナス，伏見トウガラシからの クーヘキサン，クロロホルム画分に強い 抗变異活性が照められたため，各棈クロマトグラフィーにより活性成分

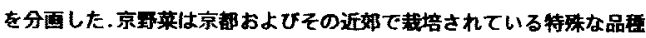
であるたけてなく、人为的通抜かほとんとされていないことから，京里

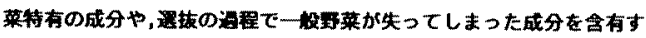
る可能性が高く，新规杭变異原の含有が期待できる.

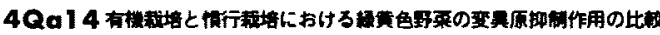

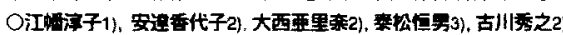

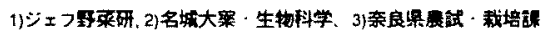

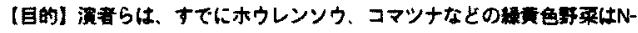

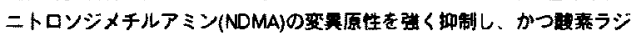

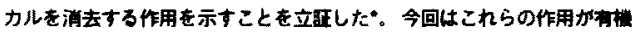

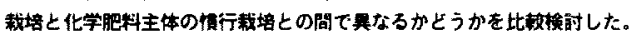

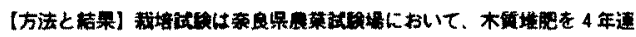

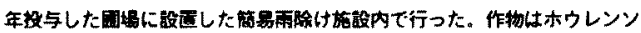

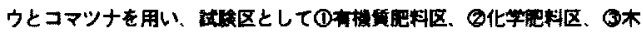

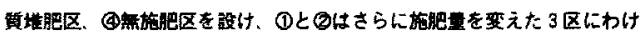

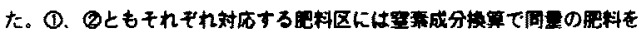

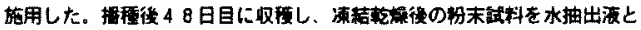

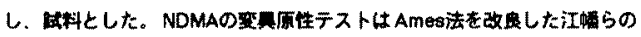

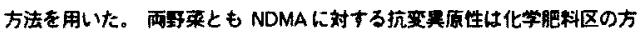

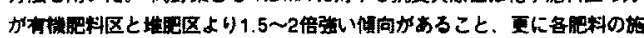

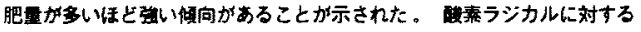
消去作用についても併せて轱告する。

- J. Ebata, K. Kewwai and H. Furkewa: Antimulagenesis and Anticar cinogenesis

Mechanisms III. Basic Lite Sciences.61, 99-102pp(1993)

4Qa15 キチン・キトサンの抗変異原性機構について

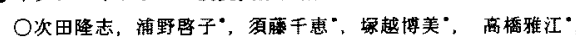
クュエン・ウァン・チュエン・加ト吉バイオ・目本好大. 物理, “日本女子大・食物

【目的】演者らはキチン及びキトサンの訜末を加熱拠理すると、発がん 性物筫へテロサイクリックアミン額に対して强い抗変異原性を示すこと を報告した。この抗変異原性は加熱処理することによって発現すること から、加整処理に上るキチン及びキトサンの結罪及び行子棈诘等の裂化

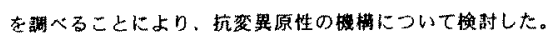

[方法と䊅果]キチン及びキトサン粉末を250てで20分問加熱したもの を語料とし、これらの抗変異原性についてはTrp-P-1を用いたAmes法で

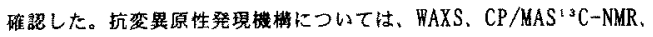
FT一IRなどを用いて、加慜されたキチン及びキトサンの满造を解析した。

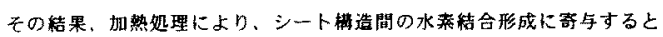

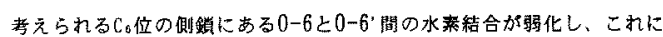

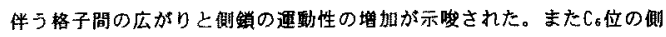
鎖に新たなカルボニル基の発生が影められた。加熱に伴うこれらの槆造

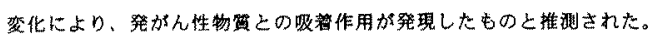

4Qp1 カマンベールチーズのTrp-P1に対する抗恋暴原性 O山田正子, 中㴔

【目的】実唤例のないカマンベールチースの抗要翼原性を、 Salmonella typhimurium TA 98株由来のストレプトマイシン依

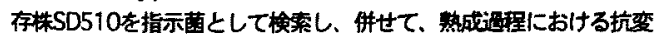
異原性の整化について酮へた。【方法と桔果】变異原物空にはア ミノ酸加熱分解物であるTrp-P1を用いた。カマンベールチー

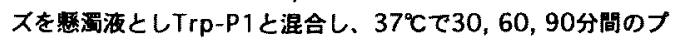
レインキュベーション後ろ過を行い、万夜を供試式料とした。 SD510は, Oxoid nutrient broth No.2 (OX) にストレブト

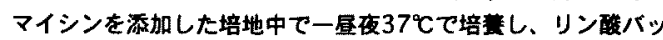

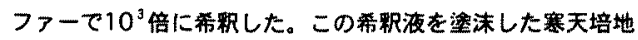
(OX agar)上のペーパーティスクに供式式料を杂み込こませ、 37 Cて48時間培舞後、出現した復州变暴コロニー数を汁測し、 抗変異原性を抑制率として求めた。その結果、短い熟成期間か ら高い抑制军を示し、さらに、プレインキュベーションの時間 による差もなかったことから、本研究て製造したかマンベール チーズは高い抗变買原性を持っていることを明らかにした。

$4 Q p 2$ フラボノイドによるTrp-P-2 の変異原性㧕制機構の解析

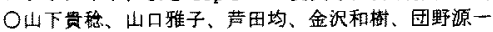
(神大脿、生物機能化学)

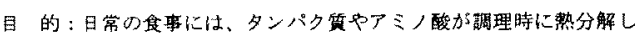
て生じた Trp-P-2などのへテロサイタリックアミンが含まれる。これ らは強い発がん前祭物啠であり、シトクローム P450醉素で活性化さ れて突然要珙を䅨し、発がん性を示寸。本研究ては、フラボノイト

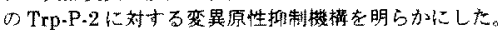

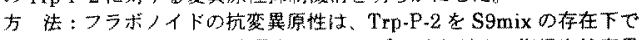

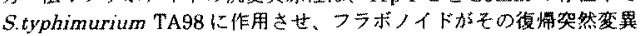
ロロニ一数をとの程度城少させるがで测定した。また、ラットのP450c 醉素(CYP1A1)と醉舟のレダクターゼを同時発現させた組換え体醏母 (AH22/pAMR2)のミクロソームを用い、Trp-P-2 が究極発がん体の N-OH-Trp-P-2 に代䐝活性化される速度を電気化学狳出器を備えた

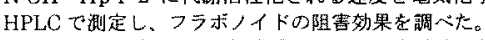

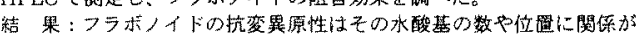
なかったのて、抗酸化能によるるのてはないと考えた。一方、フラボ /イドは湾度依存的に P450cによる Trp-P-2 の N-OH 化を阻害し、る

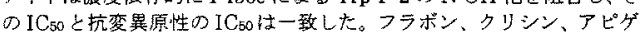
シン、ルテホリン、フラボノール、クェルセチンは非楛抗的に阻害し、 ガランジン、ケンフェロールは不描抗的であった。また、フラポノイ

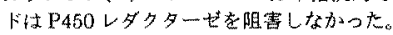

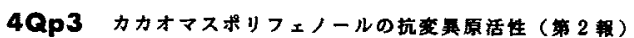

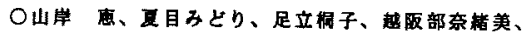

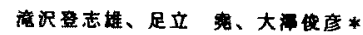

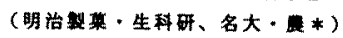

目的：活者ら昨年の本大会で、カカオマスから抽出したポリ

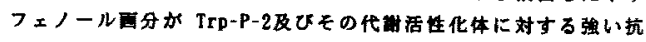

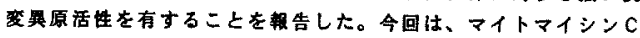

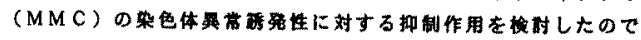
鞎告する。

方法：カカオマスの808エタノール抽出物（CUE）の抗变暴原活

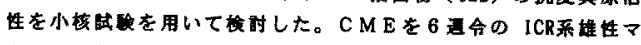

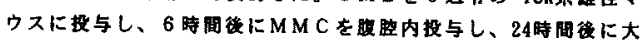

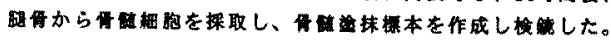

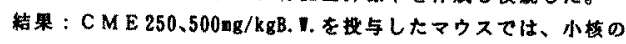

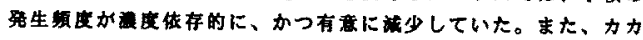
オマスポリフェノールはln vitroに於いてもMMCによるD N A

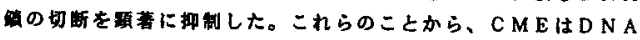

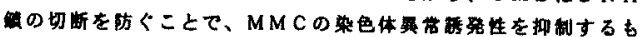
のと推柴された。 
4Qp4 萁便由来乳酸菌のTrp-P2およびIQに対する 抗变異原性

○細田正孝，山崎和幸，椅本英夫，細野明锇”

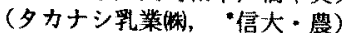

(目的〕高い抗変異原性を持つ乳酸菌を用いて製造した発

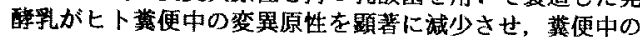
Lactobacillus およびBifidobacterium が有億に增加した ことを先に報告しだ'、今回，発醉乳を投与したヒト罴便 中より乳酸菌を吩離し、Trp-P2およびIQの変異原性に対す る抑制奻果を検討した。

[方法〕新鮮な七ト蓝便から光岡らの方法によってLactobacillusおよびBifidobacteriun を分耀し, API シスデによ って簡易同定した，それらの中31菌株の涷結乾曒菌体を用 いて, Trp-P2およよびQに対する抗変異原性効果をS.typhi一 murium TA98 株を指標菌として湘定した。 その結果，全て の供試菌株はS-9 存在下で特政的な抑制好果を示し， $L$. rhamosus 3K21侏はTrp-P2および1Qの変異原性に対し，そ れぞれ82X、63.9\%の高い抑制率を示した。

1) Hosoda et al. J. Dairy Sci. 79. 745(1996)

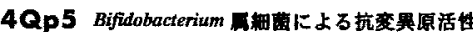

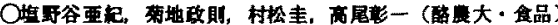

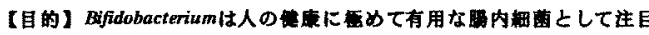

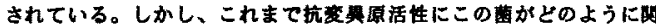
わっているかについての知見がそしいと思われる。そこて、本研究は ヒト由来のBifidobacteriumを用い、本貫汃ニトロ化合物ておるAF-2と

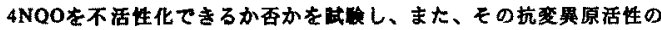
槄を明ら加にした。

【方法と結果】ヒト由来ておるBifidobacterium の type strain 5萧株に対

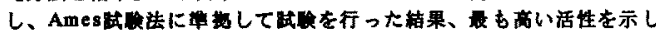

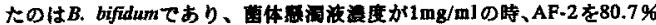
抑制した。また、Bifidobacteriumによる要奥原物犋の械少县をHPLCて

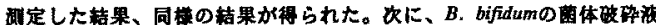

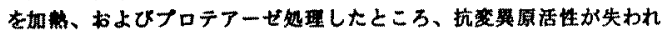

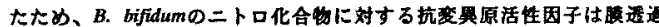

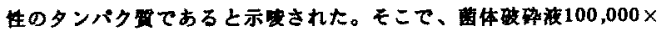

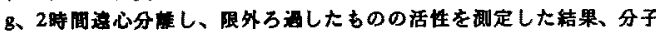

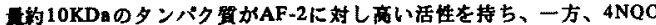
では200KDa以上と的20KDaのものに高い佸性を示した。現在、菌体

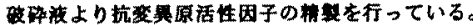

4 Qp6 The role of Lactobacillus acidophilus and Biffobacterium longum in binding and antimutageniciy to potent aminoacid pyrolysates O Sreokumar. $O$. and Akiyoshi Hosono Faculty of Agrlculture, Shinshu Universtity.

Lactobacillus acidophilus possesses anticarcinogenic, hypocholesterolemic and antagonistic activities. Recent studies have reported the in vive role of $L$. acidophilus and $B$. Longum but no comparison on antimutagenicity and binding with aminoacid pyrolysates and the identification of potent strains will be helpful in developing strains for use as a food adjunct.

Binding was assayed by HPLC analysis and antimutagenicity using a streptomycin dependent strain SD 510 of $S$. typhimurium TA98.

Antimutagenic and binding properties of 28 strains of Lactobacillus acidophilus and 2 strains of Bifidobacterium longum on the mutagenicity of amino acid pyrolysate, 3 amino- 1,4 dimethyl-5H pyrido $(4,3-b)$ indole (Trp-P1) was investigated in vitro using Streptomycin dependent strain of Salmonella typhimurium TA 98. Among these, 4 strains of $L$. acidophilus (strains $4,17,26$ and 28 ) and one strain of $B$. longum (strain 29) exhibited highest percentage of antimutagenicity and binding. The other factors influencing the mechanism of binding like, cell and mutagen concentration, $\mathrm{pH}$ and incubation time also studied. $2 \mathrm{mg}$ cells bound with $88-95 \%$ of $0.2 \mathrm{mg}$ of Trp-P1 in 30 minutes at $\mathrm{pH} 7.0$ in all the strains. The maximum amount of mutagen bound was $0.12-0.13 \mathrm{mg}$ per milligram of the lyophilized cells. Other amino acid pyrolysates like Trp-P2, IQ, MEIQ and Glu-P1 were also tested for the binding ability of these strains. The role of crude cell wall and the isolated petidoglycan along with the purified cell wall in binding also reported.

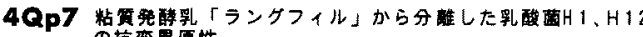
の抗变暴原性

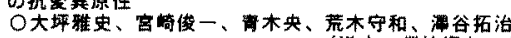

(道立工莱技術センタ-

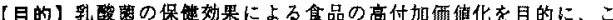

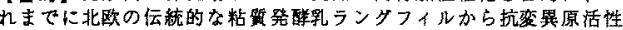
をもつ乳酸眾 Lactococcus lactis subsp. lactis H1及びLactococcus

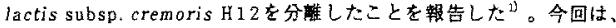
H 1、H12の抗变翼原性のメカ二スムを解析した。

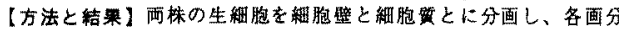

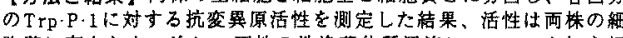

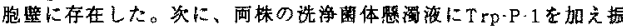
とう後遠心分噰し、得られた獭集と上洁のTrp・P・Iを定昌した結果、 大部分のTrp.P.1加菌体に存在した。このことよりH1、H12の Trp.P-1に対する抗変異原性は、菌体によるTrp-P-10結合による

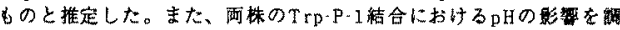

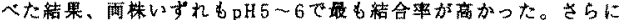
Trp-P-1のpKa 测定の結果、 $\mathrm{pKa}$ aは7.7であった。Trp.P-1は人テロ

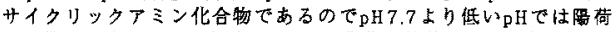
馣を带び、またそれより高いpHでは非荷电状態になると推定した。 以上より、H1、H12のTrp·P-1に対する抗変異原性は、細胞壁表

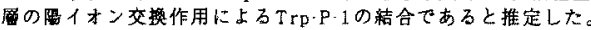

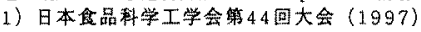

4 Qp8 Mutagenicity of Tauco and Desmutagentc Activity of Maillard Feaction Products Against Mutagenic Heated Tauco O Usman and Akiyoshi Hosono

Faculty of Agriculture. Shinshu University

1. Tauco, an Indonesian traditional fermented food, contained high proportion of protein and is consumed atter heat treatment applied during cooking A number of researchers have reported that mutagens are produced duing cooking of protein-rich tood. The offect of heating time and temperature on the mutagen formation in sweet and salky lauco was investigaled. The desmulagenic activity of Maillard reaction products of lysine or glycine with glucose preparad by heating at vafious temperature and pH against mutagenic swoel and salty tauco was also stugied.

2. Mutagenicity studies were carried out according to Maron and Arnes. Taster strains used wore streptomycin dependent (SD) 510 strain derived from Salmonalla typhimurium TA 98 and original histidine and biotin dependent TA 98 , from the culture of our laboratory.

3. Ethanolic extracts of sweet and salty tauco exhibited a dose-felated muthencts mula plate. Mutagenicity was delecled in wheated and healed sweet and salty tauco. Addlich of me mulagercat act lauco, but docresed the mulagonicily of ina heact saly heating lemperature on the mulagenicity of sweat and salty lauco showed that mulagenicily was increased with increased healing lemperature, while heating time generally increased the mulagen formation in the range of 15 to $45 \mathrm{~min}$. Desmutagenic activity of Mallard reaction products prepared from lysine-glucose was higher than those prepared from glycine-glucose against the mutagenicty of both sweet and salty lauco. It was also found that desmutagenicity of the reaction products increased with the increase in heating temperature, and the highest Inhibition was observed in resction products prepared by heating at $120^{\circ} \mathrm{C}$ for $30 \mathrm{~min}$ at pH 11

4Qp9 Streptococcus thermophilus 1131 株菌体へのIrp-P-1の㠷着

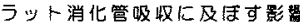
○寺原正樹、目黑幸子、金子勉（明治乳亲（株）中研）

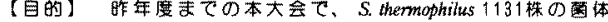

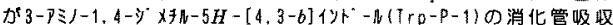
を阻㕩することを in situ あょひ in vivoの実駼系で明らかにし

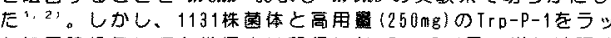

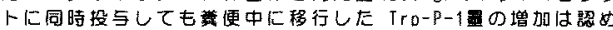
られなかつだ!。そこで、本研究では、ラットに比較的低用跑

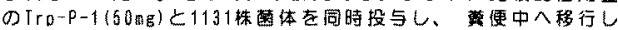

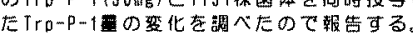

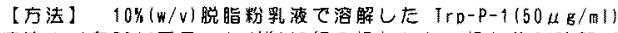

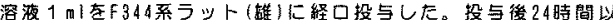

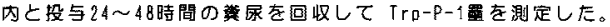

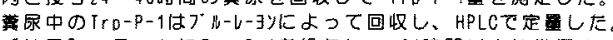
【結果】ラットにTro-P-1投与し、24時間以内に便め人

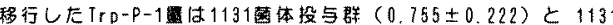

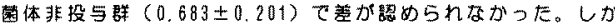
し、TrD-p-1投与24〜48時間で便中へ移行したTrp-P-1国は

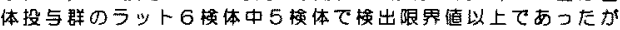
圈体非投与群のラットでは 6 検体全てが换出されず、模出率に

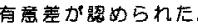

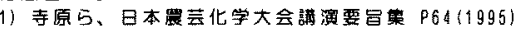

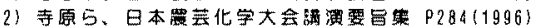




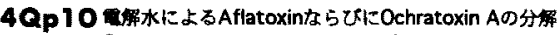

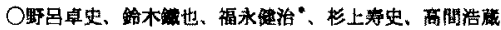

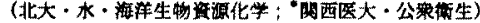

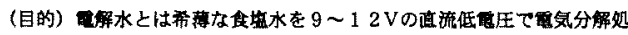

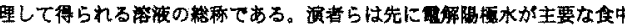

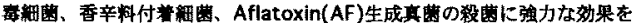
示すことを㫼告した。また、解胆栖水がAflatoxin B1(AFB1)を分解す ることも数估した。今回惊、AFB1以外のAFならひたOchratoxin A(OCA)

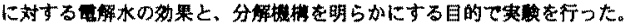

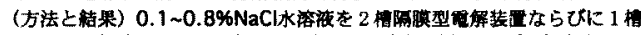

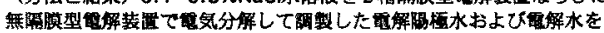

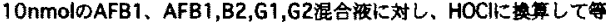

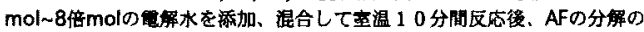
有箱 HPTLC(Silica Gel, chloroform:acetone=9:1; UVA),HPLC(ODS, $\left.25 \mathrm{~cm} \times 0.46 \mathrm{~mm} ; \mathrm{CH}_{3} \mathrm{CN}_{2} \mathrm{H}_{2} \mathrm{O}=35: 65 \mathrm{v} / \mathrm{v} ; \mathrm{Ex}=365 \mathrm{~nm}, \mathrm{Em}=412 \mathrm{~nm}\right) \mathrm{k}$

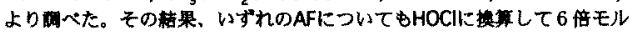

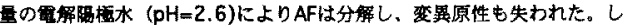

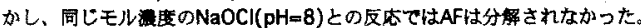
したかっって、AFの分雕に间与する化学相はOC゙ではなくHOClおよびそこ

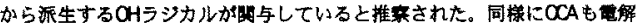
隔唡本により分解されることが明らかたされた。

\section{Qp 11 科油

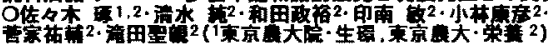

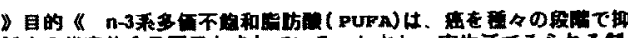

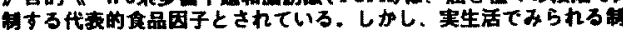

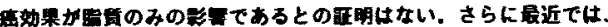

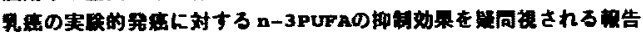

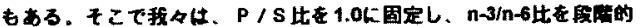

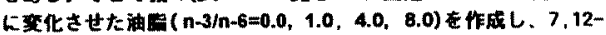

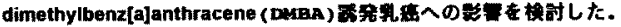

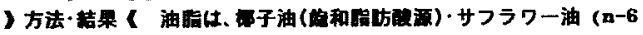

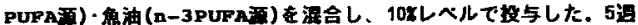

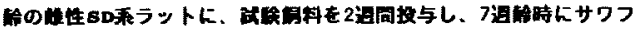

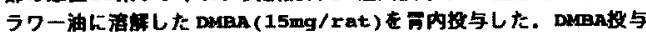

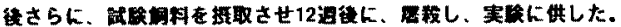

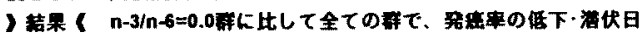

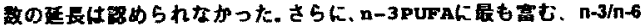

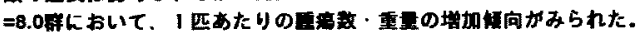

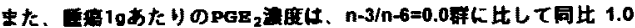
群にわいて低下したが、それ以上钭の n-3/n-6比を高内ても有意な

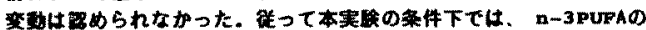

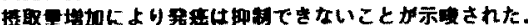

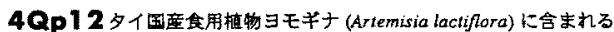

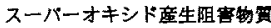

○大音良美、河本紀店、中㭙宣督、村上明”、小清水弘一”

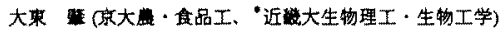

[目的] 我々はこれまでに、スーバーオキシドの廣生睢が発がんブロモー

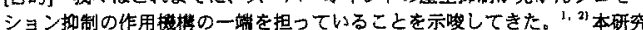

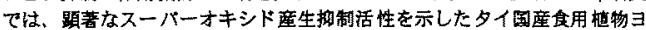
モギナ (Artemisia lactiflora，キク科)に含まれる活性成分の究明を試みた。

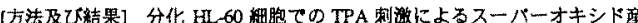

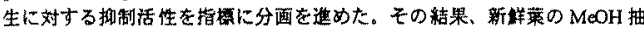

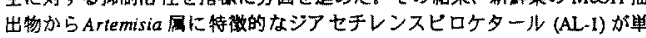

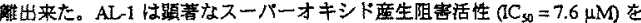
示したばかりでなく、発がんブロモーターによる細胞内遥酸化物の生成や Epstein-Barr virus の活牦化を有意に

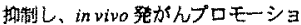

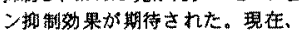

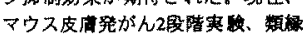

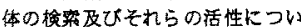

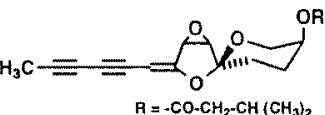
て䖽时中である。

1. A. Murakami, et al., Oncology, 53, 386-391 (1990).

AL-1

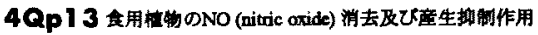

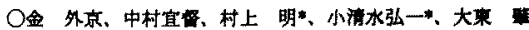

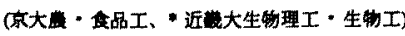

[目的] 近、的等NO合成酸素 (inducible NO syntbase iNOS) によって通

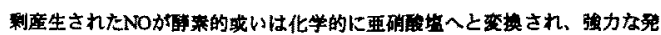

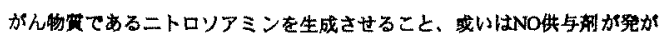
んプロモーション活性を示すことが筑告されている。従って、NOの消去や

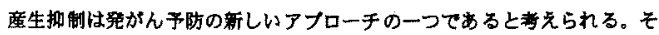

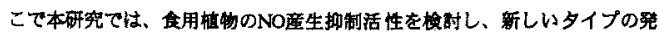
がん予防物变を得ることを目的とした。

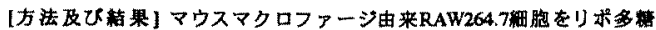

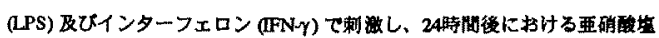
量としシトルリン量を测定した。和座会用植物(メタノール抽出物63程)の

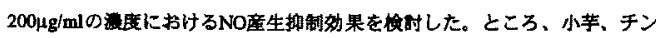
ゲンサイ、セレベス、バシル、エシャレット及びアホホカドなどか高い船

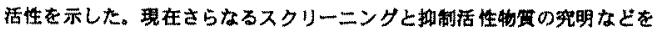
試みている。

4 Qp 141 -acetoxychavicol acelateの活性酸塞座生排制作用

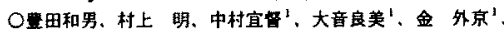

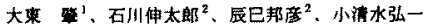

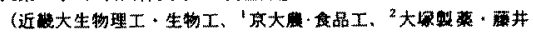
s:念研究所)

[目的] 1'-acetoxychavicol acetate (ACA)は、琴带産ショウカ科贯用植

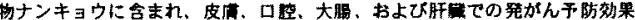

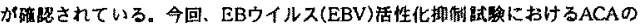

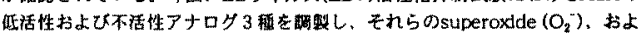

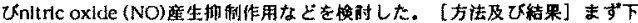

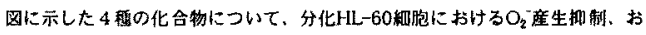

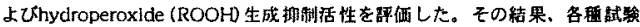

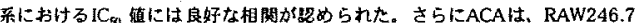

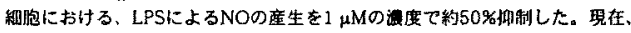

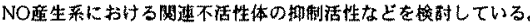<smiles>[R20]Oc1ccc(C([R3])(C=C)OCC)cc1</smiles>

\begin{tabular}{|c|c|c|c|c|c|c|c|}
\hline & & & & $<1$ & $c_{5}$ & M) & \\
\hline & $\mathbf{R}_{\mathbf{l}}$ & & & EBY & $\mathbf{O}_{2}$ & & $\mathrm{OH}$ \\
\hline$\overline{\mathrm{ACA}}$ & $A c$ & AC & $\mathbf{H}$ & 1.3 & 4. & & 29 \\
\hline MeACA & Ac & AC & Me & 26 & 29 & & 16 \\
\hline HC & H & H & H & $>100$ & $>100$ & $>1$ & \\
\hline HCA & H & Ac & H & $>100$ & $>100$ & $>1$ & \\
\hline
\end{tabular}

4Qp15 ニカショウガに含まれる発がん㸡物盆zerumbone

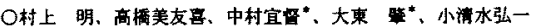

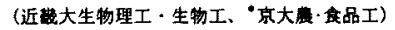

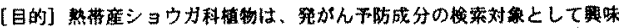
浓い秦材てある゙、秘々が行った、EBウイルス(EBV)活性化抑制佸性のスク

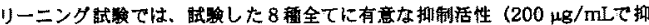

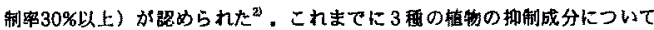
報告したが、今回の研究ては、ニカショウカ (Zingiber zerumbet) の根茎に

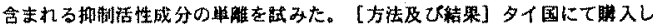

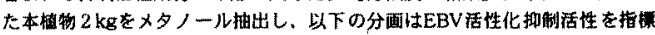

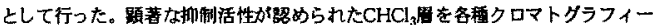
で分圂すると、主要抑例活性成分として、zerumbone $(1 ， 1.4 \mathrm{~g})$ と関臬物留 の $\alpha$-humulene $(2,7.9 \mathrm{mg})$ 単解できた。 1 は、晻い $\mathrm{EBV}$ 活性化抑制活性を示し た $\left(\mathrm{IC}_{50}=0.14 \mu \mathrm{M}\right)$ か、 2 㹥全く不活 性 $\left(\mathrm{IC}_{s,}>100 \mu \mathrm{M}\right)$ であり、8位

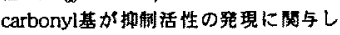

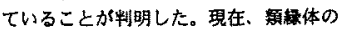

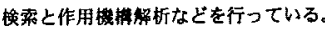

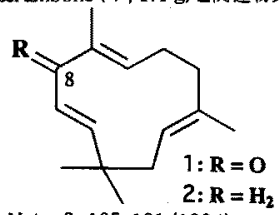
1) A. Murakaml et al., Asla Pacific J. Clin. Nutr., 3, 185-191 (1994). 2) A. Murakaml et al., Cancer Lett., 9 5; 139-146, (1995). 


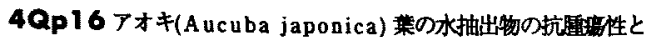
モの作用僟作

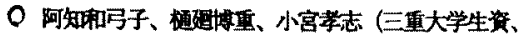
医技知)

（目的）アオキ(Aucuba japonica) 菜の水抽出物にソルビン酸と

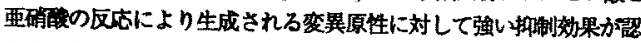

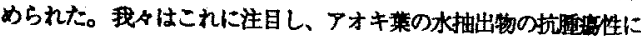
ついて梌尉した。

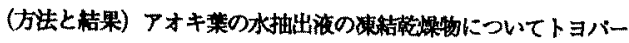
ルHW40Sのゲルクロマトを行い、画分1 1,2,3を得て、これらを抗

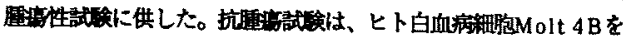

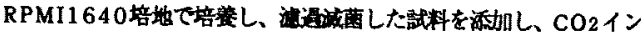

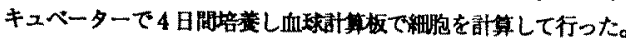

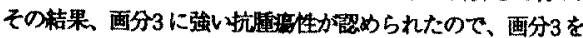

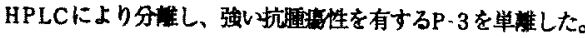
つぎに培諅湅䛌からDNAを抽出し、これをアガロースゲル電気

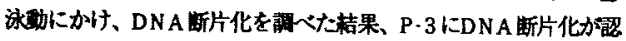

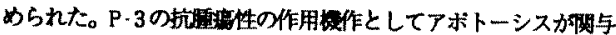
していると考えられる。

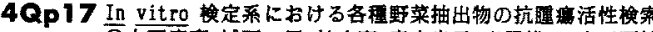

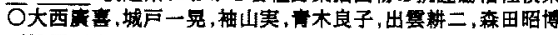
(㭠屋研究所)

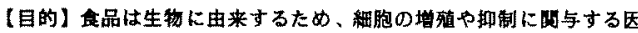
子の存在が期待される。そこで、先に、マウスSV40形页枟换細胞を用

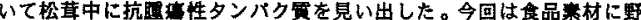

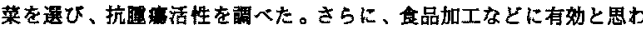
れる呧分子物貫についても検时した。

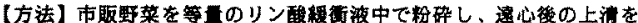
粗抽出波として第一次スクリーニングを行った。有奻と判定した野莱

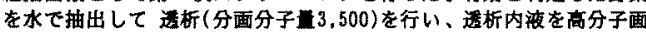
分、唀析外满を低分子画分として第二次スクリーニングを行った。活

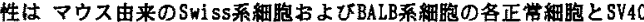

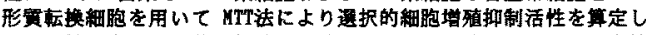
た。活性を有した野菜の低分子画分については酸酸エチルによる有機 漈媒分面を行い、同機に活性を㳔定した。

[結果]第一次スクリーニングの赫果、フロッコリー、ダイコンなと 15程類の野菜が有妙であった。これらの中で低分子画分に活性を有し たものは、カイワレダイコン、ショウガなど8種類であった。さらに、 有機溶媒分画の結果、カイワレダイコン、ショウガでは中性物筫が活 性成分の主体でることなどが推定された。

4Qp18N-ニトロソビスオキソプロピルアミン(BOP)投与によるハ

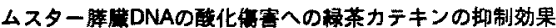
○田原正一、金子孝夫、高林小み代*、原田昇*(都老人研、 *前网県大 - 短大)

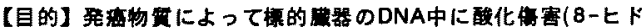
ロキシデオキシグアノシン: 8-OHOG)が生ずることが知られてい る。BOPの投与によるハムスター䑏麇DNA中の8-OHdG生成に対 する粶莱カテキンの种制効果を倹时した。

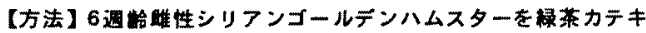
准与群( $0.1 \%$ カテキン含有水)と対照群(水道水)に分け、BOP $(20 \mathrm{mg} / \mathrm{kg} \mathrm{bw} /$ week) を皮下投与した。投与後、時間を变えて

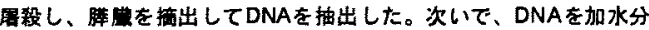
解し、8-OHdGをHPLCで検出矵定した。

【洁果・考察】BOP單回投与では、8-OHdGは耐群とも投与後增

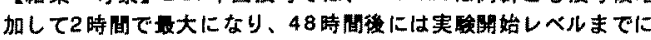
回復した(2，6 時間磁で対照群は有帻心高值)。BOP3回投与では、 カテキン投与群は笚回投与とほほ同粎の変化を示したが、対照群

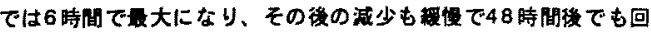

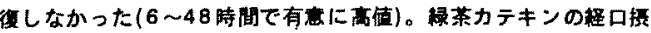

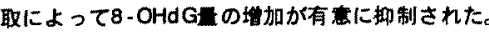

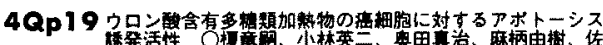

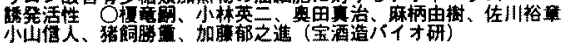

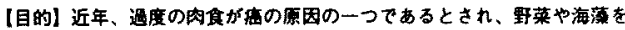
多く掑取する基生活が注目されている。其用橲物にはべクチン、アルギ

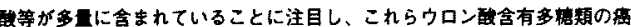

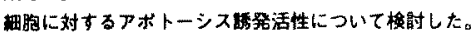

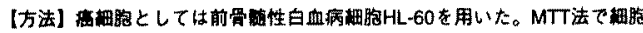
塔愐を測定し、DNA断片化とアポトーシス小体の形成を钼察してアポトー

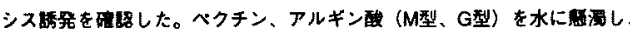

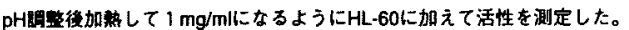

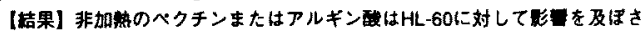
なかったが、 $\mathrm{pH} 7$ で $1211^{\circ} \mathrm{C} 、 30$ 分加㷛したべクチン、pH3.3で121C、2 時

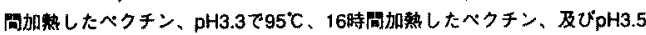

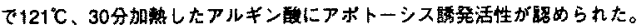

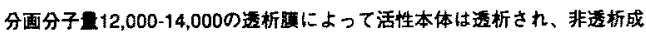

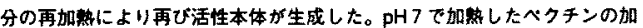

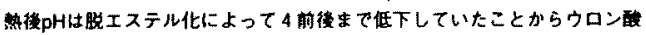

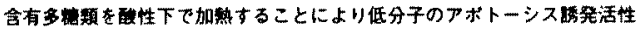

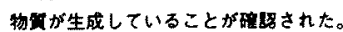

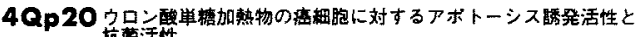
热骦话惟

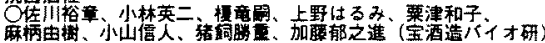

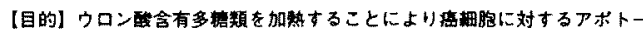
シス原発活性が生ずることが明らかになったのでその梅成成分であるウロ

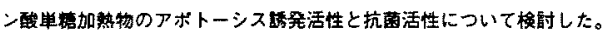

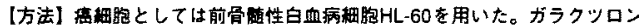
䣬、グルクロン酸、グルクロノラクトンを水に沿解し、様々なpHで加熱後

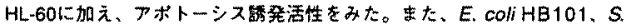
aureus $3 A, S$. typhimurium LT2、P. aeruginosa, $P$. fluorescens, $B$.

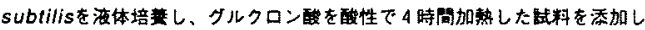
て抗菌活性をる。

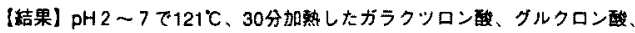

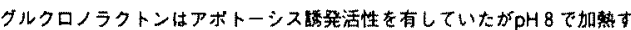

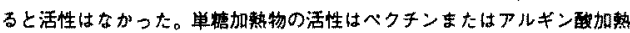
物の活性よりも数倍から数十倍強かった。加熟グルクロン酸はグラム陽性 と隆性の湅菌に対して幅広い抗菌活性を持つことが明らかになった。ウロ

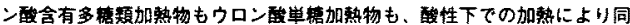

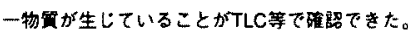

4ap21ラット初代培蓄肝細胞に対するへテロサイクリックアミン類 の軣胞性について 芦田均、○㙁谷文章、足立哉、金 沢和樹、団野源一 (神大典、生物機能化学)

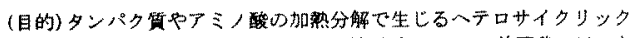

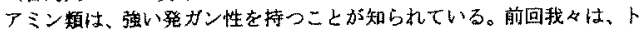
リプトファンの加熱分解物である Trp.P.1 がラット初代培黄肝縕胞に 対して强い䄉胞毒性を示すことを報告した 1。本研究では、Trp-P-1と 他の6 種類のヘテロサイクリックアミン類の細胞嗐性を比㜞した。

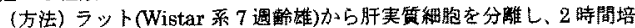

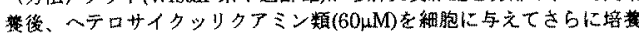

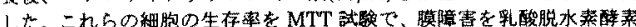

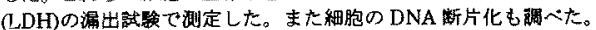

(結果) Trp-P.1 は、培盖 6 時間大 MTT 代謝活性の低下やLDH 漏出

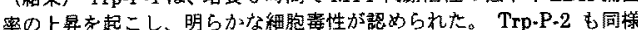
の稩胞性を示したが、Trp-P.1のそれよりも弱加た。一方、PhIP IQ.MelQ、MeIQx、A( $\alpha) \mathrm{C}$ と $\beta$-carboline 類(ハルマン、ハルミン、ノル

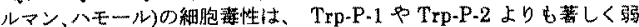
加た。たTrp.P.1 や Trp-P-2 は、綀胞の形態藉しく变化させる とともに、核の DNA を断片化させた。従って Trp-P-1 や Trp-P-2 に 上万細胞毒性の発現は、アポトーシス梖道によるものと考えた。

1) 1995 年度日本苌芸化学大会講演要旨集 p 324 
4Qp22トリプトフナンの加熱分解物 Trp-P-1 による肝細胞のアポト

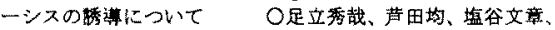

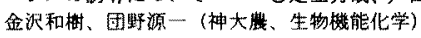

（目的）トリプトフテンの加熱分解物である Trp-P-1 は、弦い変異原

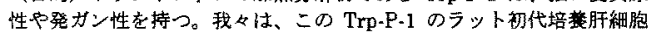
に対する細胞性を研究してきた。本研究では、Trp-P.1による肝綶胞

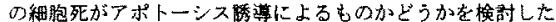

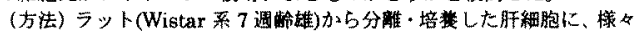

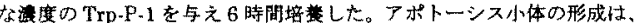

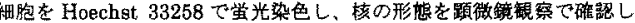
た。DNAの断片化は、アガロース電気泳動で即べ、断片北率は、核か ら遊㒕した DNAをDAPIを用いて定量した。

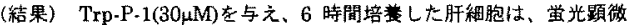
鏡て核の形热異常が絸察された。二の稩胞から DNAを抽出し、アガロ

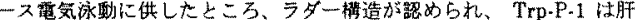

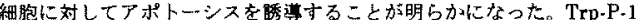
による肝稩胞の核 DNA の断片化恃、程時的かつ渡度传存的であった。

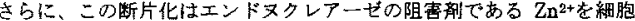

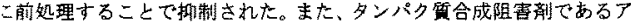
クチノマイシンDやンクロヘキシミドの前処理は、Trp-P.1に上る

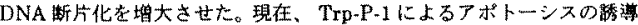
作用についてさらに㛟討を加えている。

\section{Ra3 造伝子工学食品の品質評価 : ダイス通伝子転换} ジャガイモにおける成分変敛

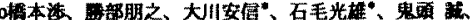

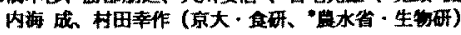

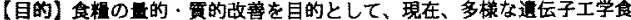
品が設新されている。これらの选伝子工学余品が実用化されるためには、 是品としての品筫が確保されなければならない。本研究ては、タイスの主

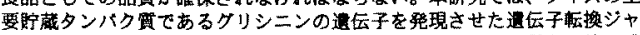
ガイモ（品程：メイクイーン）について、安全性を含めた品票を、特に成

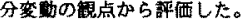

【方法】クリシニンにテトラメチオニンを捚入した改造型およひ天然型グ リシニン遗后子を、ジャガイモ塊茎特異的タンバク實であるハタチンのフ 口モ一夕一を用いて器現させた。ジャガイ气塊茎㭠成成分の含量を湘定し ベクターのみを等入したジャガイモ拈よひ天然ジャガイモのそれと比較し F。

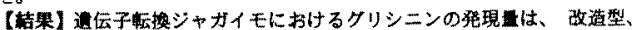
天然型とも、全タンバク贯の約 $1 \%$ 程度であった。造伝子転换シャガイモ

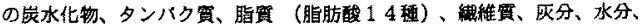
アミノ酸 18 種、ヒタミン 10 種、ミネラル 7 程の含量は、対照と同程度

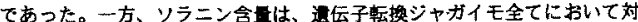
照の1.5〜2倍に增加した。チャコニン今量も增加した。現在、買伝子

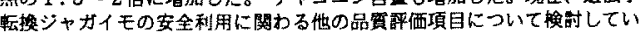

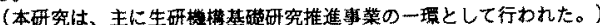

$4 \operatorname{Ra} 4$

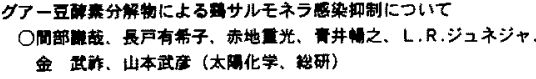

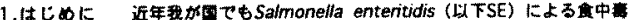

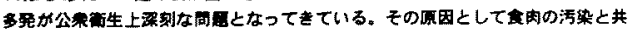

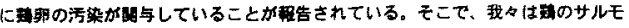

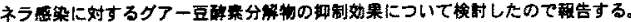

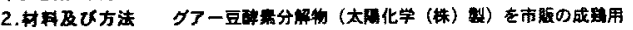

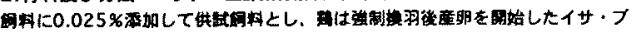

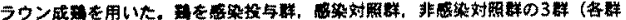

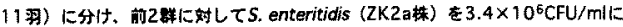

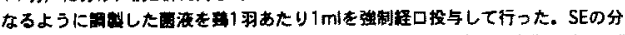

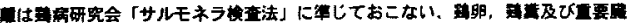

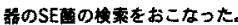

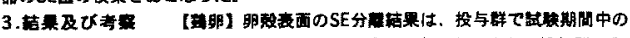

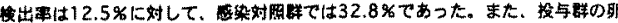

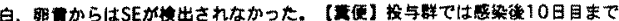

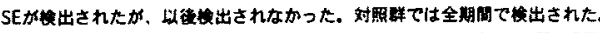

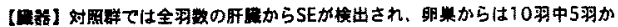

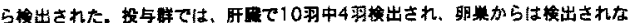

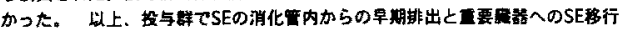

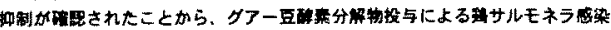

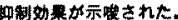

4Ra5 植物性食品の大晹菌および黄色ブドウ球菌に対する抗 菌活性 ○小野晴宽"，手崎新子田辺釗一，渡辺道子 (東京学芸大・教育、*すかいらーく研)

[目的]食習畒のなかに見られる抗菌性食品の抗菌活性を検討 し、寄与する成分と抗菌機檕を解明することを目的とした。

[方法と結果］ E. coliとS, aureusの 2 菌株に対する抗菌活 性を湘定した。わさび、からし、バナナ、パクチのメタノール 抽出物に活性が認められた。ながでも、アブラナ科植物、特に わさびで高い活性が認められ、メチルスルフィニルアルキルイ ソチオシアナート類が主として抗菌活性に寄与した。アブラナ 科植物のエーテル抽幽物について、HPLCで定量されたメチルス ルフィニルアルキルィソチオシアナート類の含谓と抗菌活性は 高い相関を示した。両菌株に対して、短鎖アルキルの方が長鎖 アルキルよりも抗菌活性が高かった。メチルスルフィニルアル キルイソチオシアナート類は、E. coliに対して $1000 \mathrm{ppm} て ゙ 、$ S. aureus に対して2000ppmで殺菌作用を示し、籼菌作用以下 のi度で、E. coli に対して100ppm 以上で、S. aurous に対 して500ppm以上でで增殖抑制作用を示した。

4Ra6 からしの抗菌成分

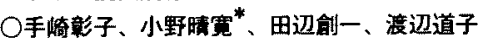

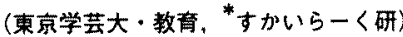

[目的] アブラナ科植物の種子には抗菌性成分が存在する。本研 究は、抗菌成分を単離・同定し、抗菌作用樴搆を解明すること を目的とした。

[方法および結果] E. coli に対する抗菌性をEEMブイヨン培地の 胆汁末の变色から测定した。睍脂カラシ種子のメタノール可溶 性・酸性画分に活性が認められた。この画分をODSカラムを用 いたHPLCで0.1\%TFA水溶液ーメタノール溶出すると、メタノー ル流度45-50\%で渍出する2個の活性成分が単離された。US、 NMRおよびIRスペクトルから、これらの活性成分は4ーヒドロキ シー3-ニトロフェニル䣫酸およびシナピン酸（3,5-ジメトキシー 4-ヒドロキシ桂皮酸) と同定された。どちらの化合物でも 100ppm以上の渡でE. coli およびS. aurousの增殖を㧕制し た。情造・活性相関については検討中である。

4Ra7 Lactobaclllus gassetl の生座するバクテリオシンの精制 とその特性

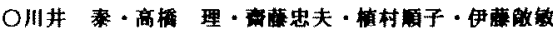

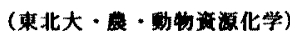

1 目的 ブロバイオティクスとして有用な L. acldophllusダルー フ乳碏菌には、バクテリオシンを生産するものが多く見出だされて

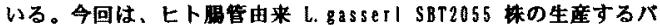
クテリオシンを単し、その諸性買の顺时を目的とした。

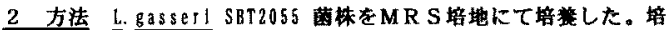

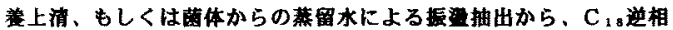
クロマトグラフィーによりバクテリオシンを単・棈其し、部分ア

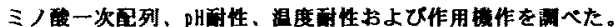

3 結果 MRS培地培爰上清、および菌体水抽地画分からパクテ

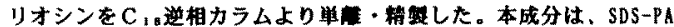
GEにより分子量約 5.4kDaの柬水性ペブチドと推定され、 $\mathrm{pH} 2$ 11

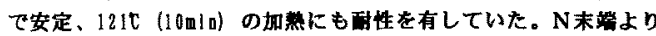
アミノ鹿一次是列を 16 残基决定したところ、上、acidophllusダル 一プ酸菌 ㄴ.10hasonll 由来のバクテリオシシ.ラクタシンFと 50\%の相同性があり、ダループ間における相成性が示㬐された。 
4 Ra8 Escherichia coli 0157:H71によるカイワレ大根の実験的 污染

○岩城正昭 ${ }^{1}$, 小沼博隆 ${ }^{2}$, 伊藤嘉典 ${ }^{1}$, 小西良子”, 春

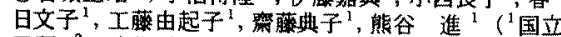
予研, 2 国立衛試)

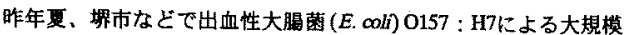
な食中毒事件が発生し、カイワレ大根がその原因食品之推定された。 今回我々は、E. coli O157:H7でカイワレ大根程子を实験的に污染し、 以後の蔽の動向を棝へた。

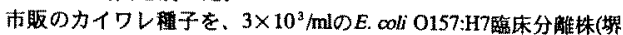

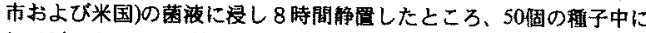
$2 \times 10^{4}$ の0157:H7が検出された。種子を減菌水中に移しさらに24時 間静置すると、理子 50 個あたりの菌数は $3 \times 10^{8}-4 \times 10^{\circ}$ に增大した。 一方、種子を $1 \times 10^{3} / \mathrm{ml}$ の0157:H7を含む菌被に浸し、水を加えなが 57-8日間生育させたところ，成舆したカイワレの可食部(上部3 $\mathrm{cm}) 50$ 本あたり $1.4 \times 10^{8}$ の菌が㛟出された。これらの結果より、カイ ワレ大根種子が 0157:H7に污染された埸合、発茅期客む生育初期 に急速な菌の增殖が起こり、その後可食部に菌が維持されることが 示睖された。

可食部の菌数は塭化第二水銀による1分間の表面殺菌処理で $1 / 1000$ に减少し、5分間の处理後には生残莐は检出されなかった。菌の同在 性について現在さらに検討中である。

4Ra9 芽胞菌胞子の無加憼高压殺落

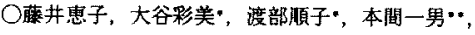
大越ひろ.

（山形大数育，*日女大食物，**キューヒ一一研究所）

【目的】食品菜材が有しているフレーバーや色がよく保持されれる加工 法として高圧が利用されている。しかし、芽胞菌胞子が充分に殺菌で きないなどその限界も示され、近年では加熟との併用が検討されてい る。本研究では、無加熟で芽胞菌胞子を殺罒することを目的として、 不活性ガスの柾水性水和に筧目し、アルゴンを浴存させ高王処理する 殺菌法について椮討した。

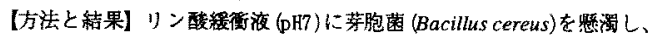
加热により栄塊細胞を死滅させ胞子のみとしたものを試料とした。こ れにア゙ルコンを充分に溶解させた後、試料容器に封入し高圧処理に供 Lた。高压处理後 Nutrient agar培地て $30^{\circ} \mathrm{C}$ 、48時間培管して生菌数 を湘定し芽胞菌胞子の生存率を求めた。500\% Pa、40 $\mathrm{C}$ 操作条件ては アルゴンを溶存させた試料の生存军は、溶存させなかった陚料と比へ て低下しなかったが、500kPa、20兄では生存慗が低下した。加圧時間 が長い方がその奻果は顕著であった。以上の結果から、アルゴン溶存

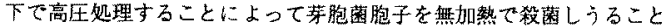
が示睃された。

4Ra10 電解水に上る等素食中毒毒（エンテロトキシン）の分解

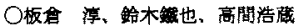

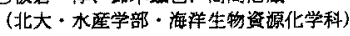

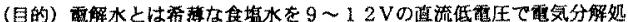

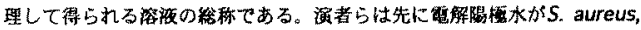

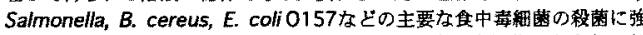

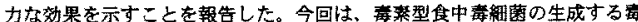
素タンパク貫（エンテロトキシン）が電解水によって分解失活するか否か を检封し、興味深い結果を得たのて報告する。

(万法と結果) Staphylococcus aureusおよびBacillus cereusが生成す る等タンパク買Staphylococcal enterotoxin A, Bacillus toxinの精慗

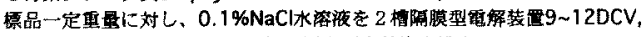

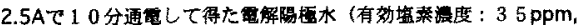

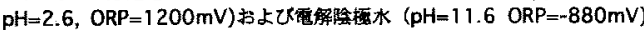
を容樌比にして $1 \sim 10$ 倍添加し、空温で数分〜 30 分接整させた後、道

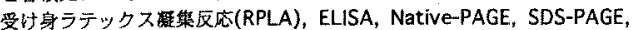

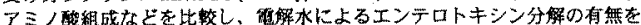

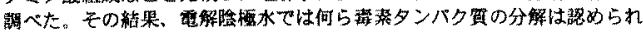

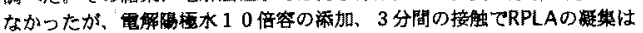
彭少られなくなり、PAGEバターンからもタンバク筧分子の分裂、低分子 化が㯊められた。エンテロトキシンの分解にはHOClと、派生するフリーラ シカルの関与が推㛝された。
4Ra11ソフトエレタトロンを用いた米の殺䁖

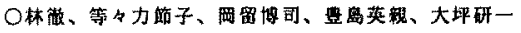
(食㗭研)

[目的] 加工原材料として使用す万無菌の米を得るためには、品 幊劣化を起こさずに米を殺蔽する技街がないので、洗米して除菌し ているのか現状である。低エネルギーの西子線であるソフトエレク トロンは造遗力が非炗に小さいのて、米の表面しか当たらず、品算 変化をほとんと起こさずに耓整できる可能性汃ある。そこて、玄米

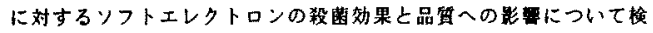
村した。

[方法と結果]数物を均一かつ碓实に回枟させるために、振漂と

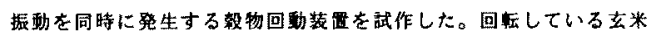

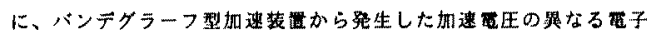

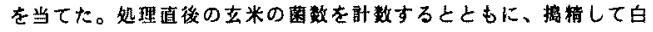
米を调製してテクスチャーやTBA值を测定した。170keV上上の要子は

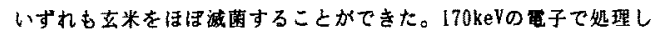
た去米は90X、180keVの雨子で処理した玄米は88\%の步留まりでそれ それれ措することにより、策子の当だった部分加除去され、テクス チャ一やTBA值に对する処理の影は现められなくなった。

4Ra12 T 校原レセプタートランスジニックマウスを用い

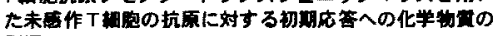
铛

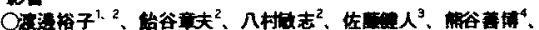

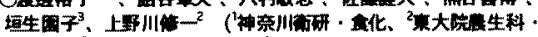

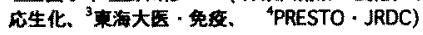

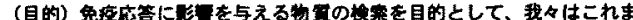

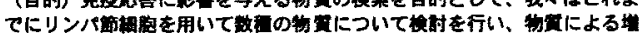

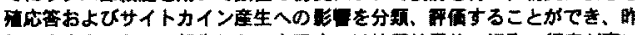

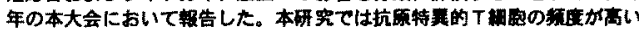
T用胞レセブター (TCR) トランスジェニック(Tg)マウスを用いてT 椾

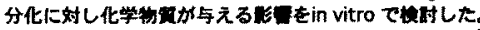

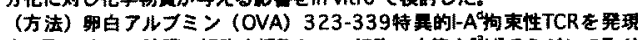

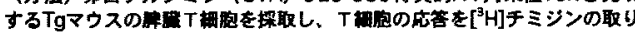
闪とMTSアッセイにより解析した。阷料とともに，OVA323-339

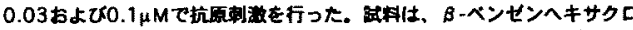
ライド(B-BHC)、p,p'シタロロビスクロロフェニルエチレン (p,p'-DDE)、クロルニトロフェン(CNP)、アセチルクエントリリフチル

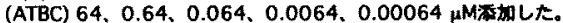

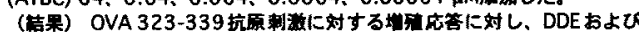

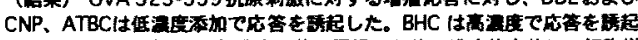

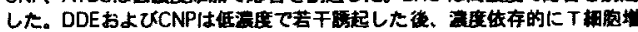

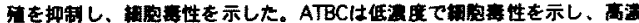

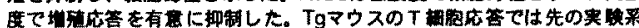

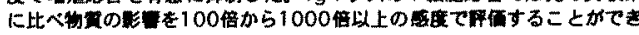
た。

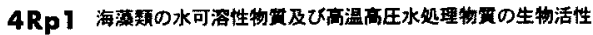
中込和载

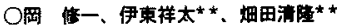

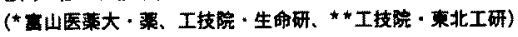

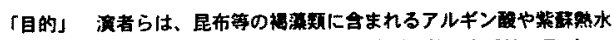

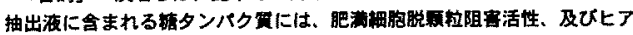
ルロニターーぜ阻宣活性があることを見いだしてきた。これらの活性物真は

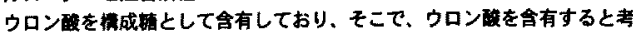

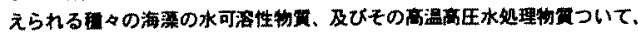
その生物活性を明らかたした。

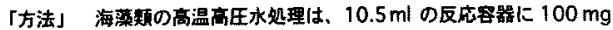

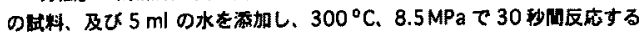
ことにより行なった。

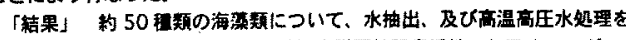

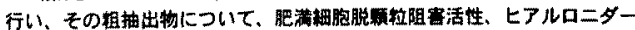

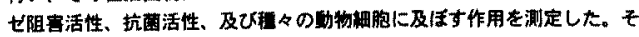

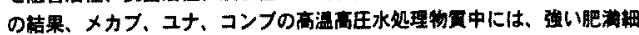

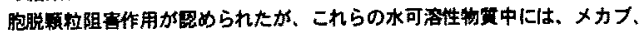

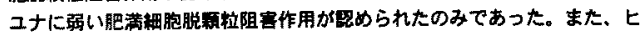

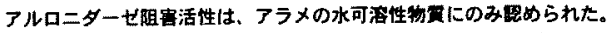

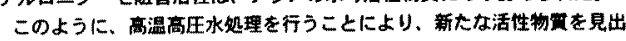
す可能性が示㖫された。 


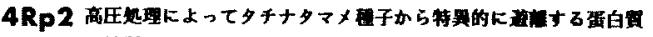

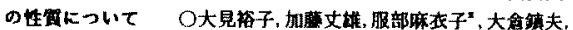

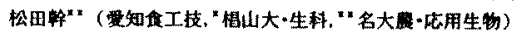

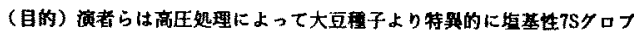

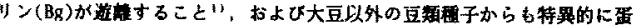

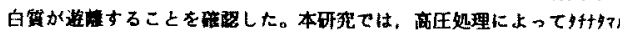

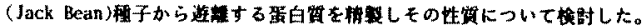

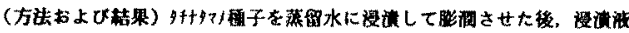

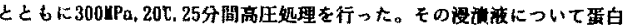

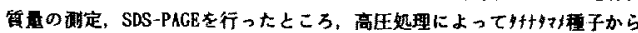

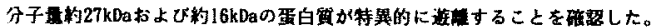
これらの蛋白算のN末璔了ミ/酸眼はBgの各サフユニットと相同性を有

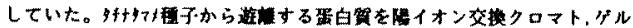

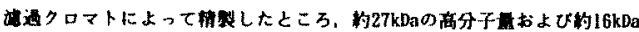

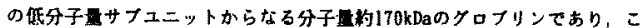

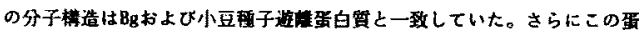

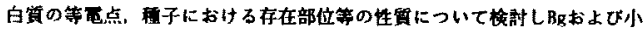

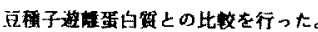

1) Oni, Y. et al. . J. Agric. Food Chew. in press.

$4 \operatorname{Rp} 3$

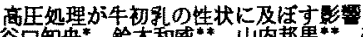

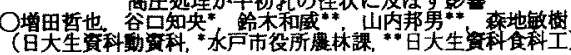

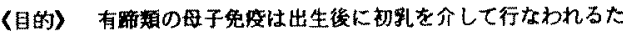

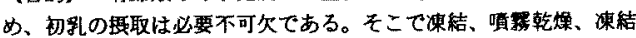
乾媒、乳酸菌を添加しての発醉など初乳に保存性を付与する方法が

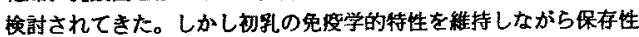
を向上することは踓しく、さらに投与時の利便性を考虑し、高压処 理年初外の可能性について检討した。

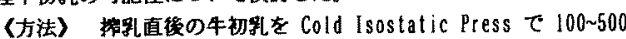
Mpa, 15分，室温で观理後、4Cで最長35日保存し経時的に絊菌数を 澌定した。また高正処理後の免度グロブリンの性状について主に免 陵化学的手法で検討した。

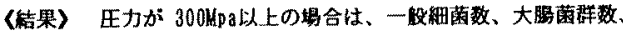
低温勫菌数の增加は著しく抑制された。特に大跀菌群は35日後にお いてもほとんど增加しておらず、高王处理による保存性の付与が礁

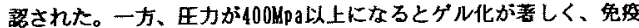

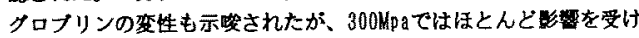
ず、コロナウイルスに対する中和抗体価も変化しないことが確諗さ れた。

4Rp4 牛礼中カぜインミセルの加㛃による巨大化の機相

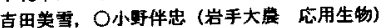

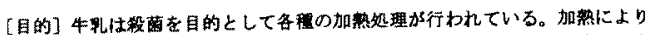

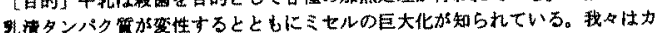

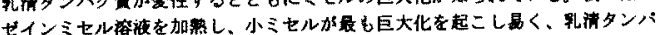

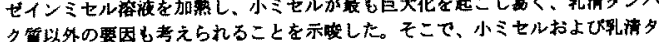

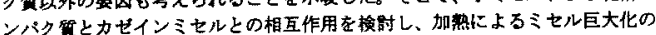
楼槽解析した。

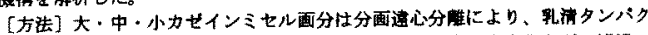

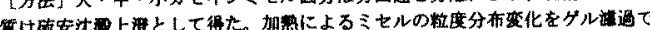

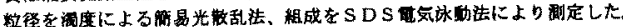

[結啭]カせインミセルを粒径により大(

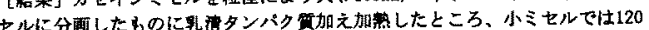

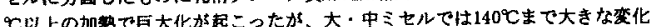

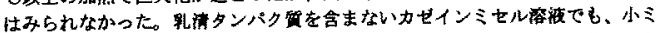

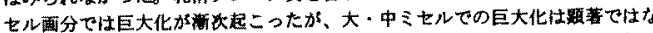

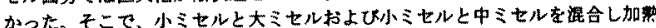

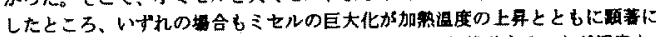

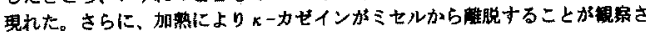
れミれルとらし結合が可能になるしのと考えられた。こ机らのことから、

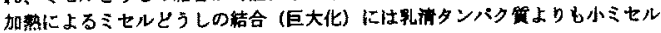

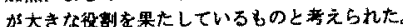

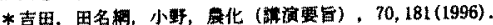

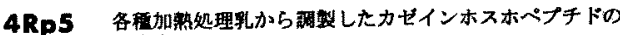
組成変化

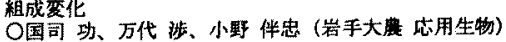

[目的]カぜインホスホベプチド(CPP)はカルシウムの吸收促淮加果

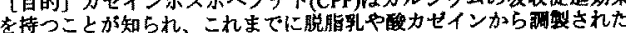

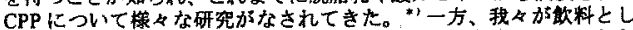

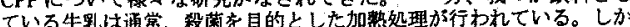

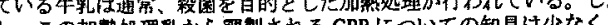
し、この加整処理乳がら网的される CPPについての知見は少なく、 CPP生成に対する加整の影都はほとんと知られていない。本研究て

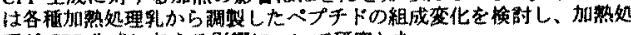
理か5 CPP生成に每える影整について研究した。

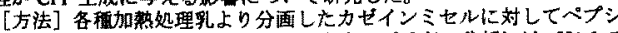
シトリプシン連続処理を行った。生成ぺプチドの分析には pH4.6

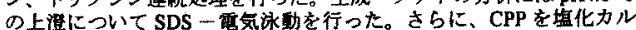

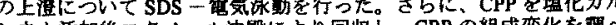
シウム添加後エタノール砄段に上り回収し、CPPの組成变化を請へ るために Q-Sepharose FFによるイオン交换クロマトクラフィーを行 、各ペプチトに份畔した

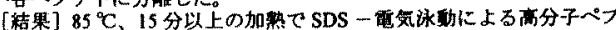

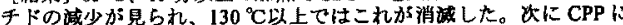

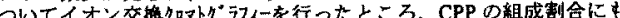
ついてイ才 变化が驾められた。このうち主要成分である $\alpha$ Sl-CN-5P(59-79) $\beta-C N-4 P(1-25)$ の相対割合に影著な変化が見られ、未加警では aS1-CN-5P(59-79)が要な成分であったが、加熟処理により $\alpha-S 1-C N-5 P(59-79) \omega$ 割合は娍少し、B-CN-4P(1-25)の割合が增加 L

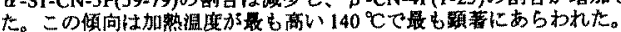

*T, Ono et al., Biosci. Biotech. Biochem., 58, 1376 (1994)

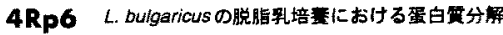
○并䖯放司（九東海大典）

【目的】Lactobacillus delbrueckii subsp. bulgaricus (L.bulgaricus)

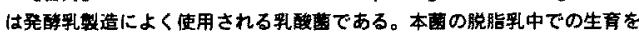

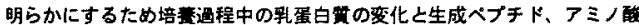

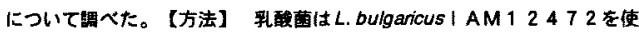

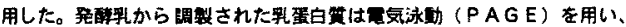

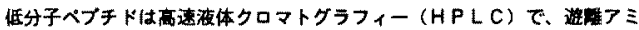

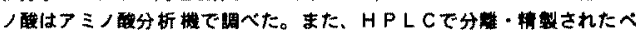

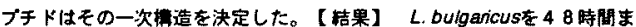

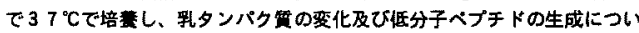

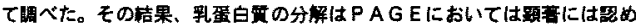
られなかった。しい、低分子ベブチトをを逆相系カラムを用いたHPLC

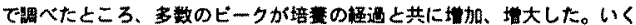
つかのピークを分取し、その一次都造を決定したところ、BーCNの（ 57-72)、(176-188)、(193-207) 加电められた (現在その他のへブチドも分析中)。避誰のアミ酸としてはZ，P，V， およひしが多く生成した。培基温度の造い(30、37、4 $\left.2{ }^{\circ} \mathrm{C}\right)$ による

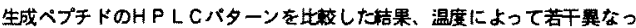

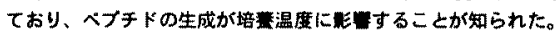

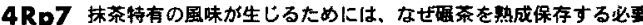
があのか ( ○四田和子、村上佳子、村中洋子

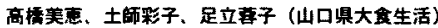

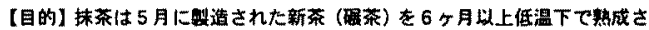

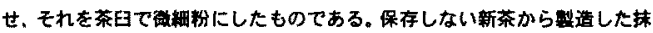

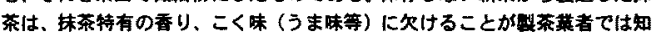

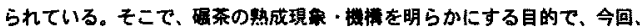

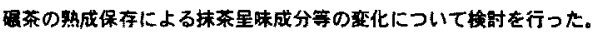

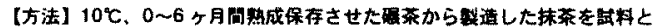

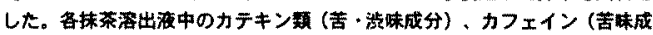

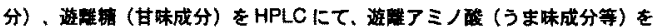
アミノ酸分析計にて、ベクチンをカルバソール法、サポニンをフェノール㼛

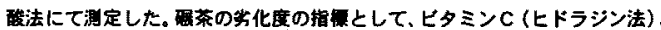
色消 (L,a,b) を温定した。

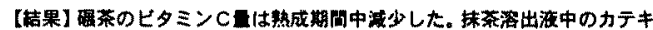

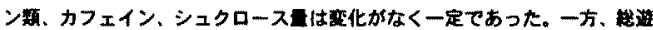

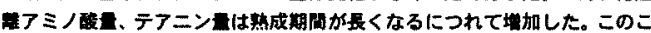

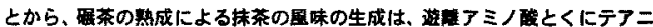

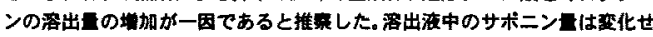

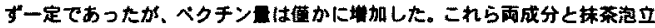

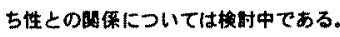




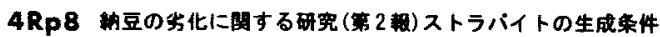

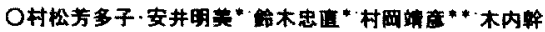

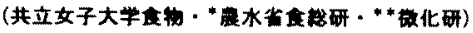

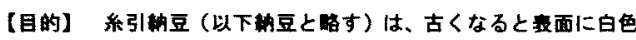

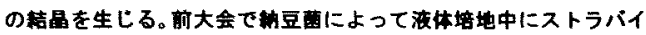
ト(リン酸マグネシウムアンモニウム)の桔晶が生成することを鋉 告した。本年度はリン酸、マグネシウム、アンモニアの此を交えて

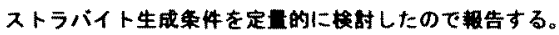

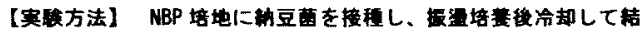
晶化させた。培寒浓のアンモニアは Fーキットアンモニアを用い、

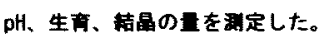

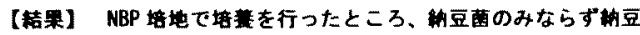
苗以外の枯草菌でも同样の結晶が生じた。500n1 吸ロフラスコに

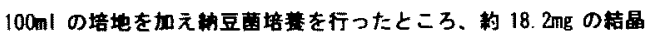

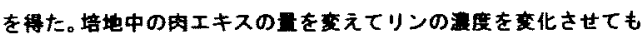

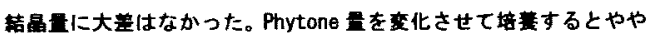

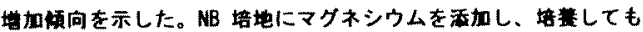
耛鹃の生成は見られなかった。

4Rp9 请国箬（Chung-kuk-jang）、大豆タンパク質発蟀食品およひ 納豆方的発数する掩発性物質について

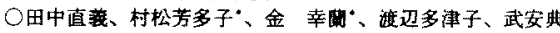
代”、金井幸子”、木内翰”（共立女短大・生活、“共立女大。 家政)

清国简（斡国で調味料の一硬として食へられている納豆菌利用の大 豆食品)、大豆タンパク買に秋豆菌を增殖させて裂造した食品および 市貶納豆から発散する揮發性物質を、Tenaxを用いたパージンドラ ッフ法で漫樎L、GC・MSEGCて分析・比整した。

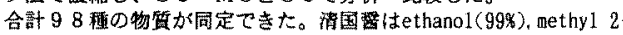
methylpropionate $(0.34 \%)$, methyl acetate $(0.26 \%)$ 加多人、大豆多之 バク質発醇食品はnethyl 2-methylpropionate(56\%), acetone(11\%), ethanol (4.9\%), שethy 1 acetate (2.9x), acetoine(13\%), 2, 5-dimethy lpyrazine(18\%)が多く、納豆はacetone (63\%), methyl 2-methylpropionate(12\%), ethanol(6.5\%), ethyl acetate(3.2\%)加多〈倹出された。 また大豆タンパク質発醇食品は2-methylpropanoic acid, butanoic acid, 3-methylbutanoic acidも他の 2 種の試料上り多く検出された。

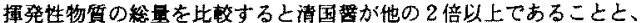

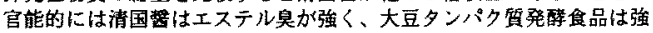
い納豆臭、もしくは強いチース臭であることから、これらの物質の存 在之存在㓶合はそれぞれの食品の臭いを反映すると考えられた。

4Rp10 ウンシュウミカン（Cions utshhiv M A Aror) の有圽利用を目 的とした 果実砟の㱔造一武作と品筫一

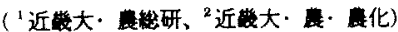

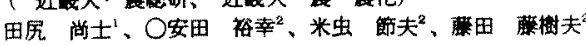

1. 目的今日、生産過剩下であるウンシュウミカンの有奻利用を目 的として果実酢の試作を行った。

2. 方法 㟫计した試料ミカンを醉母を用いてアルコール発醇を行い

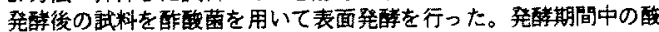
度、棈度、アルコール度、菌数を経時的に則定を行い発醉条件の检

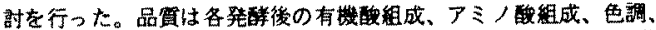

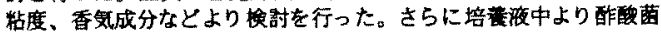
の分崔同定を行い、それぞれの菌の性筫について調べた。

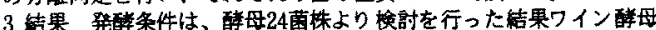
W3が最良で、27C、3日間でアルコール発醉を終了し、酷酸発醉は 30 C、5 日間で終了した。分崔した醀酸莱の同定を行った結果，

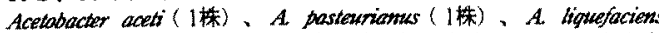
（2姝）の3種、4株であった。有機酸は他の食酷と比へると多く含 まクており、中でも柑㰌類特有の酸であるクエン酸は約200倍含ま れている。苦み成分のナリンギンは喿计の約1/2に城少した。また 香気成分も良好であることからこの果実酥はミカン特有の成陎を持 ち食酷としての利用、ドレッシンクなとの原料としての利用、さら に嫩好食品への調味絭材としての使用に期待される。

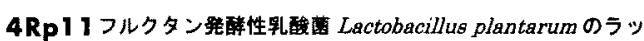
キョウ下渞発磷スターターとしての可能性 ○小林巷一，判

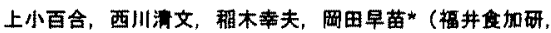
“東京脤大・圈株保存室)

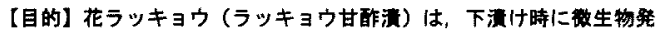
醉を行っており，その主体は，ラッキョウに多鼠に含まれるつルクタ

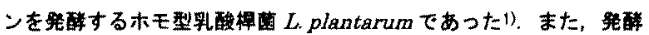

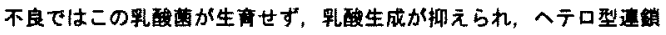
球菌 Leuconostoc mesenteroides の生成するマンニトールが蓄椣し た. そこで，発醉不安定を改暮するために，このL, plantarumを

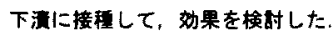

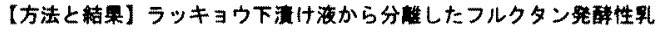

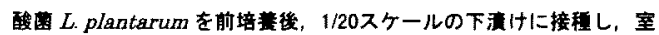

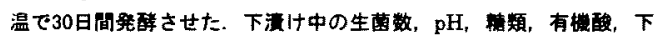

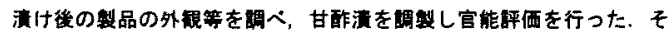

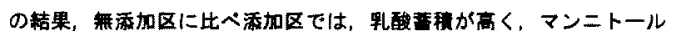

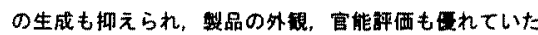

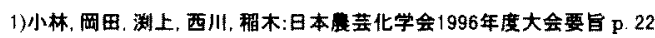

4Rp1 2 6 万性小麦の成分の性質と加工特性 ○金子成延、郡谷多一*、小前幸三**、門明美干子、松会

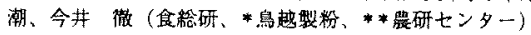

(目的)小娄では良来、もち性品種の存在が知られていなかったか、 最近になって椙次いで充成されい、新しい機能を有する食品菜材と して注目されている。本研究では、もち性小麦について、その成分 の性䝷と加工特性について調べた。

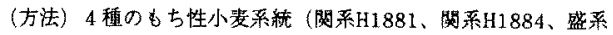

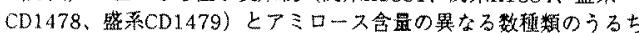
性小麦品種を用いた。これら裂粉し、ドウ及びゅでめんの㽖的粘 弹性を测定した。また、小麦粉より、デンブンとグルテンを分磪し、 それぞれの性筫を調へた。

(結果) る古性小麦のドウの動的弹性率・動的提失はバン用の強力 小麦を含めたうるち性小麦と此心゙て高い值を示し、电ち化に伴って

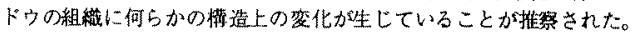
一方、もち性小考デンブンのビスコグラムは、杫化開始温度、最离 粘度時温度共に、うるち性小考デンフンに比でて低い值を示し、同 一ゅで的間てのゆでめんの動的弾性率・動的損失はアミロース含量 が低い小麦ほど低かった。

1) Nakamura et al. Mol. Gen. Genet. 248,253-259 (1995)

\section{Rp13トレハロースによる小麦物ドウの物と製バン奻果} 0 田尚文，阿部恭子(大取㾈大・落生化)

目的。トレハロースはグルコースが1，1結合した非透元性の二相で命棵

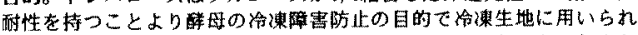
ている。近年トレハロースが安倠に供給されるようになったことより ことより小麦粉に添加して製パン性における効果蓝びにドウの物性に 对する砇霹を橹討した。

方法。トレハロース、示オトレハロース、マルトースを小麦粉材料に

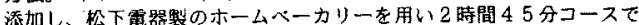
憋パンした。娔成したバンはローフホリュームを娜定後老化の程度、 およひクラムのきめを調へた。ドウの物性は湦捏了0分のものを用い レオメーター、フアリノグラフによる粘弾性、安定性、およひ蝴化调

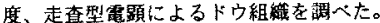

結果。トレハロース、ネオトレハロース、マルトースはいすれも $1 \%$ の添加で有意にその比容掼加增大した。製パン後の保存中のクラムの 硬さは3日閶の保存で無添加のコントロールに比へやや固くなる傎向加

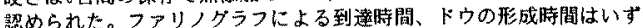

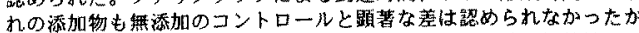
吸水本はいずれも增大した。またレオメーターによる粘弹性特性はい ずれの添加とも大きな值を示した。クラムのガスセルは高漫度でやや 大きくキメが荒くなる傾向を示したが糊化温度は明らかな差加認めら れなかった。また、走查電影によるトウ組織の亲北についても䫅討を 加え、これらの結果加らトレハロースの效果について啹告する。 